\title{
Regenstein Learning Campus at the Chicago Botanic Garden Methods
}

\section{Research Fellow:}

Sarah Hanson

Adjunct Professor

Illinois Institute of Technology

Research Assistant:

Matt Callone

MLA Candidate

Illinois Institute of Technology

Firm Liaison:

Adam White

Senior Associate

Jacobs/Ryan

This investigation was conducted as part of the Landscape Architecture Foundation's 2019 Case Study Investigation (CSI) program. CSI matches faculty-student research teams with design practitioners to document the benefits of exemplary high-performing landscape projects. Teams develop methods to quantify environmental, social, and economic benefits and produce Case Study Briefs for LAF's Landscape Performance Series.

To cite: Hanson, Sarah, and Matthew Callone. "Regenstein Learning Campus at the Chicago Botanic Garden." Landscape Performance Series. Landscape Architecture Foundation, 2019. https://doi.org/10.31353/cs1501

The full case study can be found at: https://landscapeperformance.org/casestudybriefs/regenstein-learning-campus 


\section{Environmental Benefits}

\section{- Reduces stormwater runoff volumes by $12 \%$ for a 2-year, 24-hour storm.}

Methods: The project engineer Gewalt Hamilton Associates (GHA) utilized Bentley's PondPack drainage program to calculate the reductions in runoff per 24-hour design storm for a 1-year and 2-year storm. These summated calculations provided the input for the LEED 2009 SS Credit 6.1 Stormwater Design - Quantity Control worksheet. Worksheet calculations showed that the installation of stormwater management infrastructure of rain gardens, native grass areas, and permeable pavement on the project site reduced the runoff volumes for a 1-year and 2-year storm by $11 \%$ and $12 \%$ respectively.

The total amount of stormwater detained annually was determined first by using the Center for Neighborhood Technology's (CNT) The Value of Green Infrastructure Guide runoff reduction through bioretention and infiltration equation to find the approximate amount of rainfall retained by the stormwater management infrastructure, utilizing as a basis the 1-year 24-hour storm data from the Illinois State Water Survey (ISWS). This calculation yielded 306,872 gallons per 1-year, 24-hr storm. By subtracting 16,117 gallons of runoff during a 1-year, 24-hour storm on the project site per the SS Credit 6.1 worksheet from this total, it was determined that $290,755 / 306,872$ gallons, or approximately $94 \%$, of rainwater that falls on site is detained annually by the project site stormwater infrastructure. With the determination that $94 \%$ of runoff for a 1-year, 24-hour storm is captured, the annual amount of stormwater retained on-site was calculated utilizing the variables provided by the same runoff reduction equation for bioretention and infiltration from CNT, resulting in an estimated 4,240,000 gallons of stormwater diverted annually from the sewer system.

\section{Calculations:}

Table SSc6.1-1. Site Runoff: One-Year, 24-Hour Design Storm

\begin{tabular}{|c|c|c|}
\hline & $\begin{array}{l}\text { Rate } \\
\text { (cfs) }\end{array}$ & $\begin{array}{l}\text { Quantity } \\
\text { (cf/storm) }\end{array}$ \\
\hline Predevelopment & 0.82 & 18,121 \\
\hline Postdevelopment & 0.75 & 16,117 \\
\hline
\end{tabular}

Table SSc6.1-2. Site Runoff: Two-Year, 24-Hour Design Storm

\begin{tabular}{|c|c|c|}
\hline & $\begin{array}{l}\text { Rate } \\
\text { (cfs) }\end{array}$ & $\begin{array}{l}\text { Quantity } \\
\text { (cf/storm) }\end{array}$ \\
\hline Predevelopment & 1.11 & 25,395 \\
\hline Postdevelopment & 1.03 & 23,043 \\
\hline
\end{tabular}

Table 1: LEED document for Stormwater Quantity Control SS Credit 6.1 showing calculations for stormwater runoff reduction. Source: GHA Engineers 
Rainwater detained annually

Rainwater fall on project site in 1-yr 24-hr storm $=2.51$ inches of precipitation for a 24-hr storm * $196,080 \mathrm{sf}$ of developed site area * $100 \%$ of rainfall detained ${ }^{*} 144 \mathrm{sq}$ inches/SF ${ }^{*} 0.00433$ gal/cubic inch $=306,872$ gallons of precipitation per $24-\mathrm{hr}$ storm

Percentage of water detained in 1-yr 24-hr storm $=306,872$ gallons per 24-hr storm $-16,117$ gallons of runoff in post-development 24 -hr storm $=290,755$ gallons or $94 \%$ of rainfall detained

Total Runoff Reduction Calculation $=36.89$ inches of annual precipitation * 196,080 sf of site area ${ }^{*} 94 \%$ of rainfall captured/retained ${ }^{*} 144 \mathrm{sq}$ inches $/ \mathrm{SF}{ }^{*} 0.00433 \mathrm{gal} / \mathrm{cubic}$ inch $=\mathbf{4 , 2 4 0 , 0 0 0}$ gallons

Sources:

Gewalt Hamilton Associates, Inc. LEED 2009 for New Construction and Major Renovations SS Credit 6.1 Stormwater Design - Quantity Control. PDF. Washington D.C.: US Green Building Council.

PondPack. Computer software. Exton: Bentley Systems Inc.

Table 1. Sectional Mean Frequency Distributions for Storm Periods of 5 Minutes to 10 Days and Recurrence Intervals of 2 Months to 100 Years in Illinois. PDF. Champaign: Illinois State Water Survey, 2007.https://www.isws.illinois.edu/statecli/RF/table10.pdf

US Department of Commerce, and Noaa. "Annual Precipitation Amounts for Chicago, IL." National Weather Service. January 04, 2019. Accessed June 30, 2019. https://www.weather.gov/lot/Annual_Precip_Rankings_Chicago

Limitations:

Calculations are based on computer simulations, not actual events.

- Reduces the amount of water needed for irrigation by an estimated $63 \%$ in July by planting native and adaptive species, saving $\$ 1,300$ in irrigation costs for July alone, the month with the highest irrigation demand.

As part of the Regenstein Learning Campus's LEED goals to create a water efficient landscape, a large percentage of the site is planted with native and adaptive species that do not require irrigation outside of times of extensive drought. This plant selection strategy reduces the need for irrigation by 325,922 gallons in the hottest month of July.

Methods: According to plan documents, $61,636 \mathrm{sq} f \mathrm{for} 44 \%$ of the planted area is turfgrass that requires regular watering. $69,512 \mathrm{sq} \mathrm{ft}$ or $50 \%$ of the planted area is native and adaptive species that do not require permanent irrigation. $8,629 \mathrm{sq} \mathrm{ft}$ or $6 \%$ of the planted area is a native undisturbed area that does not require any watering. 
Jacobs/Ryan Associates provided area calculations, species factors $\left(k_{s}\right)$ and density factors $\left(k_{d}\right)$ for three landscape types for the Nature Play Gardens design case compared to a baseline case utilizing the LEED 2009 WE Credit 1 (WEc1) Water Efficient Landscaping worksheet. The landscape types were turf grass; mixed trees, shrubs and groundcover; and existing native undisturbed. Both the baseline and design cases for turf grass required permanent irrigation. For mixed trees, shrubs, and groundcover, the baseline case used average values in which the planting can be maintained in acceptable condition at about $50 \%$ of the reference evapotranspiration (ETo) value with regular irrigation.

The design case, however, substitutes the mixed trees, shrubs, and groundcover with plant materials that are native and adaptive, thus requiring only temporary irrigation for establishment and backup irrigation during times of extended drought. The temporary irrigation method is hand-watering by Chicago Botanic Garden staff, which is not part of an automatic irrigation system. The existing native area is undisturbed. In summary, per the WEc1 worksheet, the baseline case requires 511,626 gallons of irrigation for July, and the design case requires 185,634 .

This represents a savings of $\$ 1,300$ in the month of July alone at a rate of $\$ 0.00398 /$ gallon, as determined by referencing City of Chicago Water and Sewer rates. 


\section{Calculations:}

Table WEc1-1. Irrigation Baseline Case (month with the highest irrigation demand)

Note: Click "Calculate" in the summary section of the table to perform the water savings calculations. "Calculate" must be clicked after any or all the data is entered in the table to refresh the calculated values and obtain accurate information.

\begin{tabular}{|c|c|c|c|c|c|c|c|c|c|c|}
\hline $\begin{array}{c}\text { Landscape } \\
\text { Type }\end{array}$ & $\begin{array}{l}\text { Area } \\
\text { (sf) }\end{array}$ & ks & $\mathrm{kd}$ & $\mathrm{kmc}^{1}$ & $\mathrm{~K}_{\mathrm{L}}$ & Eto & $\mathrm{ET}_{\mathrm{L}}$ & $\begin{array}{l}\text { Irrigation } \\
\text { Type }\end{array}$ & IE & $\begin{array}{l}\text { TWA } \\
\text { (gal) }\end{array}$ \\
\hline Mixed trees, shr+t & 69,512 & 0.5 & 1.1 & 1 & 0.55 & 6.3 & 3.47 & Sprinkler & 0.625 & $240,550.5 €$ \\
\hline Turf Grass & 61,636 & 0.7 & 1 & 1 & 0.7 & 6.3 & 4.41 & Sprinkler & 0.625 & $271,075.4 \varepsilon$ \\
\hline \multirow[t]{3}{*}{ Native Undisturb } & 8,629 & 0.5 & 1.1 & 1 & 0.55 & 6.3 & 3.47 & & & \\
\hline & & & 0 & & & 6.3 & & & & \\
\hline & & & & & & 6.3 & & & & \\
\hline Total area (sf) & 139,777 & \multicolumn{8}{|c|}{ Baseline Total Water Applied (TWA) (gal) } & 511,626 \\
\hline
\end{tabular}

Notes:

1 For each landscape type, the microclimate factor $(\mathrm{kmc})$ must be the same for the baseline and design case.

Table WEc1-2. Irrigation Design Case (month with the highest irrigation demand)

Note: Click "Calculate" in the summary section of the table to perform the water savings calculations. "Calculate" must be clicked after any or all the data is entered in the table to refresh the calculated values and obtain accurate information.

\begin{tabular}{|c|c|c|c|c|c|c|c|c|c|c|c|}
\hline $\begin{array}{c}\text { Landscape } \\
\text { Type }\end{array}$ & $\begin{array}{c}\text { Area } \\
\text { (sf) }\end{array}$ & ks & $\mathrm{kd}$ & $\mathrm{kmc}^{1}$ & $\mathrm{~K}_{\mathrm{L}}$ & Eto & $E T_{L}$ & $\begin{array}{l}\text { Irrigation } \\
\text { Type }\end{array}$ & IE & $\mathrm{CE}^{2}$ & $\begin{array}{l}\text { TWA } \\
\text { (gal) }\end{array}$ \\
\hline Turf Grass & 61,636 & 0.8 & 0.6 & 1 & 0.48 & 6.3 & 3.02 & Sprinkler & 0.625 & 1 & $185,634.42$ \\
\hline Mixed trees, shrit & 69,512 & 0 & 1.3 & 1 & 0 & 6.3 & & Temporary & 0 & 1 & \\
\hline Native Undisturba & 8,629 & 0 & & & & 6.3 & & & & & \\
\hline Total area (sf) & 139,777 & \multicolumn{9}{|c|}{ Design total water applied (TWA) (gal) } & $185,634.42$ \\
\hline \multicolumn{11}{|c|}{ Nonpotable water used (gal) } & 0 \\
\hline \multicolumn{11}{|c|}{ Design total potable water applied (TPWA) (gal) } & $185,634.42$ \\
\hline
\end{tabular}

Table 2: LEED document for Water Efficient Landscaping WE Credit 1 showing calculations for water use reduction through use of higher species factor and density of plants in the design case.

Source: Jacobs/Ryan Associates

Water needed in July: 511,526 gallons (baseline) - 185,634 gallons (design) = $\mathbf{3 2 5 , 9 2 2}$ gallons reduction

Percent water reduction: (325,922 gallons / 511,526 gallons) $\times 100=63 \%$

Cost savings in July: 325,922 gallons $\times \$ 0.00398 /$ gallon $=\$ 1,297.16$

\section{Sources:}

Jacobs/Ryan Associates. LEED 2009 for New Construction and Major Renovations WE Credit 1 Water Efficient Landscaping. PDF. Washington D.C.: US Green Building Council. 
"Water and Sewer Rates." City of Chicago: Water and Sewer Rates. June 1, 2019. Accessed June 27, 2019.

https://www.chicago.gov/city/en/depts/fin/supp_info/utility-billing/water-and-sewerrates.html.

\section{Limitations:}

In the LEED 2009 WEc1 worksheet calculations for turfgrass, although there is a higher species factor (.8) and lower density factor (.6) in the design case than there is in the baseline case (.7 species factor, 1.1 density factor), suggesting a greater irrigation need in the design case, the design case still calculates to a lower irrigation requirement. This calculation method has been removed for the WEc1 credit in later versions of LEED, which use EPA calculation standards. Thus, the watering requirement may be different in the actual design conditions.

\section{- Removes $81 \%$ of total suspended solids through natural areas, grass filters, and manufactured water quality treatment devices.}

Methods: In the LEED 2009 SS Credit 6.2: Stormwater Design - Quality Control worksheet, GHA Engineers listed the BMP type, location, percent of the site, and the total suspended solids (TSS) removal efficiency based on manufacturer's or a national or regional source. The SS6.2 worksheet took a weighted average of each BMP and totaled the weighted averages to determine the TSS removal efficiency of the site. The required LEED minimum of $80 \%$ was met.

\section{Calculations:}

Table SSc6.2-1. TSS Removal Efficiency

\begin{tabular}{|c|c|c|c|c|c|c|}
\hline $\begin{array}{c}\text { BMP } \\
\text { Type/Label }\end{array}$ & $\begin{array}{l}\text { BMP Description } \\
\text { and/or Location }\end{array}$ & $\begin{array}{c}\text { In Series } \\
\text { with BMP } \\
\text { Above? }\end{array}$ & $\begin{array}{l}\text { Percent } \\
\text { Site } \\
\text { Treated by } \\
\text { BMP }\end{array}$ & $\begin{array}{c}\text { TSS } \\
\text { Removal } \\
\text { Efficiency } \\
(\%)\end{array}$ & $\begin{array}{c}\text { Source of TSS Removal } \\
\text { Efficiency data }\end{array}$ & $\begin{array}{l}\text { Weighted } \\
\text { Average TSS } \\
\text { Removal } \\
\text { Efficiency } \\
(\%)\end{array}$ \\
\hline Water Qualit & Stormceptor \#1 & N/A & 14 & 82 & Manufacturer & 11.48 \\
\hline Water Qualit & Stormceptor \#2 & No & 18 & 82 & Manufacturer & 14.76 \\
\hline Water Qualit+ & Stormceptor \#3 & No & 41 & 83 & Manufacturer & 34.03 \\
\hline Native Plantit & Area \#4 & No & 7 & 85 & National or regional source & 5.95 \\
\hline Grass Filter & Area \#5 & No & 12 & 65 & National or regional source & 7.8 \\
\hline Native Planti & Area \#6 & No & 8 & & National or regional source & 6.8 \\
\hline \multicolumn{6}{|c|}{ Total weighted average TSS removal efficiency (must be at least $80 \%$ ) } & 80.82 \\
\hline
\end{tabular}

Table 3: LEED document for Stormwater Quality Control Credit 6.2 showing calculations for water use reduction through the use of higher species factor and density of plants. Source: Jacobs/Ryan Associates

\section{Sources:}

Gewalt Hamilton Associates, Inc. LEED 2009 for New Construction and Major Renovations SS Credit 6.2 Stormwater Design - Quality Control. PDF. Washington D.C.: US Green Building Council. 


\section{Limitations:}

This is an estimate. Manufacturer data is likely not as accurate as on-site real-time measurements.

\section{- Expands the flood storage capacity of the site by $27,078 \mathrm{cu} \mathrm{ft}$.}

Where grading activity results in soil fill in within a floodplain as in the case of the Regenstein Learning Campus, lost storage must be compensated for (compensatory storage). This protects the Learning Center building from flood damage. Per Cook County regulations for flood protection, compensatory storage must be provided, and an additional $50 \%$ flood storage capacity is required on new project sites for even more protection. Post-development flood storage on the Regenstein Learning Campus can accommodate up to 3.97 inches of rainfall at a time, which can manage a 1-hour 100-year rain event (3.56 in), 12-hour 10-year rain event (3.89 in), or a 24-hour 5-year rain event (3.80 in).

\section{Methods:}

GHA Engineers performed compensatory storage calculations for the Skokie River and Botanic Garden Lake flood zones, at stations every 25 feet along the project site, to determine the total earthwork fill and cut volumes in 0-10 year strata and 10-100 year strata flood elevations (Tables 4 and 5). The total fill volume from both flood zones equated to the amount of flood storage prior to project construction (33,960 cf), and the total cut volume from both flood zones equated to the amount of flood storage provided after project construction $(61,038)$.

The site's accommodation of flood water levels was determined by converting the postdevelopment flood storage volume from cubic feet to gallons and solving for variable $\mathrm{x}, \mathrm{x}$ being the maximum number of inches the site flood storage volume could compensate, in the CNT bioretention and infiltration equation. All values less than $\mathrm{x}$ inches, found in the Illinois State Water Surveys table of "Sectional Mean Frequency Distributions for Storm Periods of 5 Minutes to 10 Days and Recurrence Intervals of 2 Months to 100 Years in Illinois" (highlighted in yellow in Table 6), were considered to be storms for which the site could detain $100 \%$ of rainfall. The retention factor (3.94 inches) was determined through the CNT bioretention and infiltration equation. See Environmental Benefit 1 for details on how this retention factor was determined. 


\section{Calculations:}

SKOKIE RIVER FLOOD ZONE COMPENSATORY STORAGE CALCULATION

\begin{tabular}{|c|c|c|c|c|c|c|c|c|}
\hline \multirow[b]{2}{*}{ Station } & \multicolumn{4}{|c|}{ Earthwork From 0-10 yr Flood Elevations } & \multicolumn{4}{|c|}{ Earthwork From $10-100$ yr Flood Elevations } \\
\hline & Fill Area $\left(\mathrm{ft}^{2}\right)$ & $\begin{array}{c}\text { Incremental } \\
\text { Fill }\left(\mathrm{ft}^{3}\right)\end{array}$ & Cut Area $\left(\mathrm{ft}^{2}\right)$ & $\begin{array}{c}\text { Incremental } \\
\text { Cut }\left(\mathrm{ft}^{3}\right)\end{array}$ & Fill Area $\left(\mathrm{ft}^{2}\right)$ & $\begin{array}{c}\text { Incremental } \\
\text { Fill }\left(\mathrm{ft}^{3}\right)\end{array}$ & Cut Area $\left(\mathrm{ft}^{2}\right)$ & $\begin{array}{c}\text { Incremental } \\
\text { Cut }\left(\mathrm{ft}^{3}\right)\end{array}$ \\
\hline \multirow[t]{2}{*}{0} & 0.0 & & 0.0 & & 0.0 & & 0.0 & \\
\hline & & 12.5 & & 37.5 & & 0.0 & & 287.5 \\
\hline \multirow[t]{2}{*}{25} & 1.0 & & 3.0 & & 0.0 & & 23.0 & \\
\hline & & 12.5 & & 425.0 & & 0.0 & & 425.0 \\
\hline \multirow[t]{2}{*}{50} & 0.0 & & 31.0 & & 0.0 & & 11.0 & \\
\hline & & 75.0 & & 437.5 & & 50.0 & & 162.5 \\
\hline \multirow[t]{2}{*}{75} & 6.0 & & 4.0 & & 4.0 & & 2.0 & \\
\hline & & 87.5 & & 237.5 & & 112.5 & & 37.5 \\
\hline \multirow[t]{2}{*}{100} & 1.0 & & 15.0 & & 5.0 & & 1.0 & \\
\hline & & 62.5 & & 362.5 & & 125.0 & & 25.0 \\
\hline \multirow[t]{2}{*}{125} & 4.0 & & 14.0 & & 5.0 & & 1.0 & \\
\hline & & 50.0 & & 500.0 & & 62.5 & & 75.0 \\
\hline \multirow[t]{2}{*}{150} & 0.0 & & 26.0 & & 0.0 & & 5.0 & \\
\hline & & 0.0 & & 825.0 & & 0.0 & & 225.0 \\
\hline \multirow[t]{2}{*}{175} & 0.0 & & 40.0 & & 0.0 & & 13.0 & \\
\hline & & 0.0 & & 1037.5 & & 0.0 & & 387.5 \\
\hline \multirow[t]{2}{*}{200} & 0.0 & & 43.0 & & 0.0 & & 18.0 & \\
\hline & & 0.0 & & 537.5 & & 150.0 & & 225.0 \\
\hline \multirow[t]{2}{*}{225} & 0.0 & & 0.0 & & 12.0 & & 0.0 & \\
\hline & & 80.0 & & 0.0 & & 285.0 & & 0.0 \\
\hline \multirow[t]{2}{*}{235} & 16.0 & & 0.0 & & 45.0 & & 0.0 & \\
\hline & & 510.0 & & 0.0 & & 952.5 & & 0.0 \\
\hline \multirow[t]{2}{*}{250} & 52.0 & & 0.0 & & 82.0 & & 0.0 & \\
\hline & & 260.0 & & 0.0 & & 565.0 & & 0.0 \\
\hline \multirow[t]{2}{*}{260} & 0.0 & & 0.0 & & 31.0 & & 0.0 & \\
\hline & & 0.0 & & 0.0 & & 232.5 & & 0.0 \\
\hline 275 & 0.0 & & 0.0 & & 0.0 & & 0.0 & \\
\hline Total $\left(\mathrm{ft}^{3}\right)$ & & 1150.0 & & 4400.0 & & 2535.0 & & 1850.0 \\
\hline
\end{tabular}

Table 4: Skokie River Flood Zone Compensatory Storage Calculation. Source: GHA Engineers. 
BOTANIC GARDEN LAKES FLOOD ZONE

COMPENSATORY STORAGE CALCULATION

\begin{tabular}{|c|c|c|c|c|c|c|c|c|}
\hline \multirow[b]{2}{*}{ Station } & \multicolumn{4}{|c|}{ Earthwork From 0-10 yr Flood Elevations } & \multicolumn{4}{|c|}{ Earthwork From 10-100 yr Flood Elevations } \\
\hline & Fill Area $\left(\mathrm{ft}^{2}\right)$ & $\begin{array}{c}\text { Incremental } \\
\text { Fill }\left(\mathrm{ft}^{3}\right)\end{array}$ & Cut Area $\left(\mathrm{ft}^{2}\right)$ & $\begin{array}{c}\text { Incremental } \\
\text { Cut }\left(\mathrm{ft}^{3}\right)\end{array}$ & Fill Area $\left(\mathrm{ft}^{2}\right)$ & $\begin{array}{c}\text { Incremental } \\
\text { Fill }\left(\mathrm{ft}^{3}\right) \\
\end{array}$ & Cut Area $\left(\mathrm{ft}^{2}\right)$ & $\begin{array}{c}\text { Incremental } \\
\text { Cut }\left(\mathrm{ft}^{3}\right)\end{array}$ \\
\hline \multirow[t]{2}{*}{0} & 0.0 & & 0.0 & & 0.0 & & 0.0 & \\
\hline & & 0.0 & & 0.0 & & 0.0 & & 0.0 \\
\hline \multirow[t]{2}{*}{25} & 0.0 & & 0.0 & & 0.0 & & 0.0 & \\
\hline & & 0.0 & & 87.5 & & 0.0 & & 575.0 \\
\hline \multirow[t]{2}{*}{50} & 0.0 & & 7.0 & & 0.0 & & 46.0 & \\
\hline & & 0.0 & & 337.5 & & 0.0 & & 1087.5 \\
\hline \multirow[t]{2}{*}{75} & 0.0 & & 20.0 & & 0.0 & & 41.0 & \\
\hline & & 0.0 & & 537.5 & & 0.0 & & 925.0 \\
\hline \multirow[t]{2}{*}{100} & 0.0 & & 23.0 & & 0.0 & & 33.0 & \\
\hline & & 0.0 & & 612.5 & & 0.0 & & 650.0 \\
\hline \multirow[t]{2}{*}{125} & 0.0 & & 26.0 & & 0.0 & & 19.0 & \\
\hline & & 0.0 & & 462.5 & & 0.0 & & 350.0 \\
\hline \multirow[t]{2}{*}{150} & 0.0 & & 11.0 & & 0.0 & & 9.0 & \\
\hline & & 0.0 & & 137.5 & & 0.0 & & 112.5 \\
\hline \multirow[t]{2}{*}{175} & 0.0 & & 0.0 & & 0.0 & & 0.0 & \\
\hline & & 0.0 & & 0.0 & & 0.0 & & 0.0 \\
\hline \multirow[t]{2}{*}{200} & 0.0 & & 0.0 & & 0.0 & & 0.0 & \\
\hline & & 12.5 & & 0.0 & & 0.0 & & 0.0 \\
\hline \multirow[t]{2}{*}{225} & 1.0 & & 0.0 & & 0.0 & & 0.0 & \\
\hline & & 12.5 & & 75.0 & & 0.0 & & 212.5 \\
\hline \multirow[t]{2}{*}{250} & 0.0 & & 6.0 & & 0.0 & & 17.0 & \\
\hline & & 0.0 & & 725.0 & & 575.0 & & 887.5 \\
\hline \multirow[t]{2}{*}{275} & 0.0 & & 52.0 & & 46.0 & & 54.0 & \\
\hline & & 0.0 & & 1437.5 & & 2200.0 & & 1325.0 \\
\hline \multirow[t]{2}{*}{300} & 0.0 & & 63.0 & & 130.0 & & 52.0 & \\
\hline & & 75.0 & & 1550.0 & & 3600.0 & & 1262.5 \\
\hline \multirow[t]{2}{*}{325} & 6.0 & & 61.0 & & 158.0 & & 49.0 & \\
\hline & & 237.5 & & 1950.0 & & 2937.5 & & 1212.5 \\
\hline \multirow[t]{2}{*}{350} & 13.0 & & 95.0 & & 77.0 & & 48.0 & \\
\hline & & 687.5 & & 2100.0 & & 1862.5 & & 1250.0 \\
\hline 375 & 42.0 & & 73.0 & & 72.0 & & 52.0 & \\
\hline & & 1462.5 & & 1500.0 & & 1675.0 & & 1462.5 \\
\hline 400 & 75.0 & & 47.0 & & 62.0 & & 65.0 & \\
\hline & & 2150.0 & & 1187.5 & & 1037.5 & & 1512.5 \\
\hline 425 & 97.0 & & 48.0 & & 21.0 & & 56.0 & \\
\hline & & 3700.0 & & 1325.0 & & 475.0 & & 1325.0 \\
\hline 450 & 199.0 & & 58.0 & & 17.0 & & 50.0 & \\
\hline & & 4700.0 & & 1400.0 & & 400.0 & & 1475.0 \\
\hline 475 & 177.0 & & 54.0 & & 15.0 & & 68.0 & \\
\hline & & 3412.5 & & 1750.0 & & 187.5 & & 2137.5 \\
\hline 500 & 96.0 & & 86.0 & & 0.0 & & 103.0 & \\
\hline & & 1537.5 & & 3025.0 & & 0.0 & & 2812.5 \\
\hline 525 & 27.0 & & 156.0 & & 0.0 & & 122.0 & \\
\hline & & 337.5 & & 4150.0 & & 0.0 & & 2725.0 \\
\hline 550 & 0.0 & & 176.0 & & 0.0 & & 96.0 & \\
\hline & & 0.0 & & 3725.0 & & 0.0 & & 1425.0 \\
\hline 575 & 0.0 & & 122.0 & & 0.0 & & 18.0 & \\
\hline & & 0.0 & & 1687.5 & & 0.0 & & 225.0 \\
\hline 600 & 0.0 & & 13.0 & & 0.0 & & 0.0 & \\
\hline & & 0.0 & & 75.0 & & 0.0 & & 0.0 \\
\hline 610 & 0.0 & & 2.0 & & 0.0 & & 0.0 & \\
\hline Total $\left(\mathrm{ft}^{3}\right)$ & & 18325.0 & & 29837.5 & & 14950.0 & & 24950.0 \\
\hline
\end{tabular}

Table 5: Botanic Garden Lakes Flood Zone Compensatory Storage Calculation. Source: GHA Engineers.

Flood storage converted to gallons

61,038 cubic feet $\times 7.48$ gallons $/ 1$ cubic foot $=456,564.24$ 
$1-100 \mathrm{yr}$ storm intervals detained $100 \%$ by the project site $x$ inches * $196,080 \mathrm{sf} * 94 \%$ of rainfall detained ${ }^{*} 144 \mathrm{sq}$ inches $/ \mathrm{SF} * 0.00433 \mathrm{gal} / \mathrm{cubic}$ inch $=$ $456,564.24$

$x=3.94$ inches

Table 1. Sectional Mean Frequency Distributions for Storm Periods of 5 Minutes to 10 Days and Recurrence Intervals of 2 Months to 100 Years in Illinois. Units are in inches.

Sectional code

$\begin{array}{ll}01 \text { - Northwest } & 06 \text { - West Southwest } \\ 02 \text { - Northeast } & 07 \text { - East Southeast } \\ 03 \text { - West } & 08 \text { - Southwest } \\ 04 \text { - Central } & 09 \text { - Southeast } \\ 05 \text { - East } & 10 \text { - South }\end{array}$

\begin{tabular}{|c|c|c|c|c|c|c|c|c|c|c|c|c|c|}
\hline Section & Duration & 2-month & 3-month & 4-month & 6-month & 9-month & 1-year & 2-year & 5-year & 10-year & 25-year & 50-year & 100-yеa \\
\hline 02 & 10-day & 2.02 & 2.48 & 2.80 & 3.30 & 3.79 & 4.12 & 4.95 & 6.04 & 6.89 & 8.18 & 9.38 & 11.14 \\
\hline 02 & 5-day & 1.66 & 1.98 & 2.24 & 2.60 & 2.99 & 3.25 & 3.93 & 4.91 & 5.70 & 6.93 & 8.04 & 9.96 \\
\hline 02 & 72-hr & 1.53 & 1.83 & 2.02 & 2.34 & 2.70 & 2.93 & 3.55 & 4.44 & 5.18 & 6.32 & 7.41 & 8.78 \\
\hline 02 & 48-hr & 1.44 & 1.70 & 1.90 & 2.18 & 2.49 & 2.70 & 3.30 & 4.09 & 4.81 & 5.88 & 6.84 & 8.16 \\
\hline 02 & 24-hr & 1.38 & 1.61 & 1.76 & 2.03 & 2.31 & 2.51 & 3.04 & 3.80 & 4.47 & 5.51 & 6.46 & 7.58 \\
\hline 02 & 18-hr & 1.26 & 1.47 & 1.61 & 1.86 & 2.12 & 2.30 & 2.79 & 3.50 & 4.11 & 5.06 & 5.95 & 6.97 \\
\hline 02 & $12-\mathrm{hr}$ & 1.20 & 1.40 & 1.53 & 1.77 & 2.01 & 2.18 & 2.64 & 3.31 & 3.89 & 4.79 & 5.62 & 6.59 \\
\hline 02 & 6-hr & 1.03 & 1.21 & 1.32 & 1.52 & 1.74 & 1.88 & 2.28 & 2.85 & 3.35 & 4.13 & 4.85 & 5.68 \\
\hline 02 & 3-hr & 0.88 & 1.02 & 1.13 & 1.30 & 1.47 & 1.60 & 1.94 & 2.43 & 2.86 & 3.53 & 4.14 & 4.85 \\
\hline 02 & $2-\mathrm{hr}$ & 0.81 & 0.95 & 1.05 & 1.20 & 1.36 & 1.48 & 1.79 & 2.24 & 2.64 & 3.25 & 3.82 & 4.47 \\
\hline 02 & 1-hr & 0.65 & 0.76 & 0.84 & 0.96 & 1.09 & 1.18 & 1.43 & 1.79 & 2.10 & 2.59 & 3.04 & 3.56 \\
\hline 02 & 30-min & 0.51 & 0.60 & 0.65 & 0.75 & 0.86 & 0.93 & 1.12 & 1.41 & 1.65 & 2.04 & 2.39 & 2.80 \\
\hline 02 & $15-\mathrm{min}$ & 0.37 & 0.44 & 0.48 & 0.55 & 0.63 & 0.68 & 0.82 & 1.03 & 1.21 & 1.49 & 1.75 & 2.05 \\
\hline 02 & $10-\mathrm{min}$ & 0.30 & 0.35 & 0.39 & 0.45 & 0.51 & 0.55 & 0.67 & 0.84 & 0.98 & 1.21 & 1.42 & 1.67 \\
\hline 02 & $5-\min$ & 0.17 & 0.19 & 0.21 & 0.24 & 0.28 & 0.30 & 0.36 & 0.46 & 0.54 & 0.66 & 0.78 & 0.91 \\
\hline
\end{tabular}

Table 6: Highlighted values are selected storms for which the project site is estimated as capable of retaining $100 \%$ of stormwater. Source: ISWS

Sources:

Compensatory Storage Exhibits. PDF. Vernon Hills: Gewalt Hamilton Associates, Inc., April 24, 2015.

Table 1. Sectional Mean Frequency Distributions for Storm Periods of 5 Minutes to 10 Days and Recurrence Intervals of 2 Months to 100 Years in Illinois. PDF. Champaign: Illinois State Water Survey, 2007. https://www.isws.illinois.edu/statecli/RF/table10.pdf

US Department of Commerce, and Noaa. "Annual Precipitation Amounts for Chicago, IL." National Weather Service. January 04, 2019. Accessed June 30, 2019. https://www.weather.gov/lot/Annual_Precip_Rankings_Chicago

Limitations: The Regenstein Learning Campus project site is approximately 4.5 acres, or $0.02 \%$, of the 22 square mile Skokie River watershed, and as such the site does not have a measurable effect on regional flooding. This information is based on models and was not independently verified in the field. 
- Added 57,201 sf of new habitat, resulting in 101,572 sf of habitat for pollinators and wildlife. The site attracts at least 11 observed species of birds and mammals including chipmunks, red-winged blackbirds, and grackles.

As part of the Regenstein Learning Campus' LEED goals, the project utilized the Nature Play Gardens to protect and restore wild life habitat. 19,732 sq ft of existing native planting area was preserved during construction, and $81,840 \mathrm{sq} f \mathrm{ft}$ of native plantings were added. Native plants were selected in order to optimize the amount of habitat created for native wildlife species. Approximately, 24,639 sq ft of habitat was lost during construction for the Learning Center building and the installation of a service road.

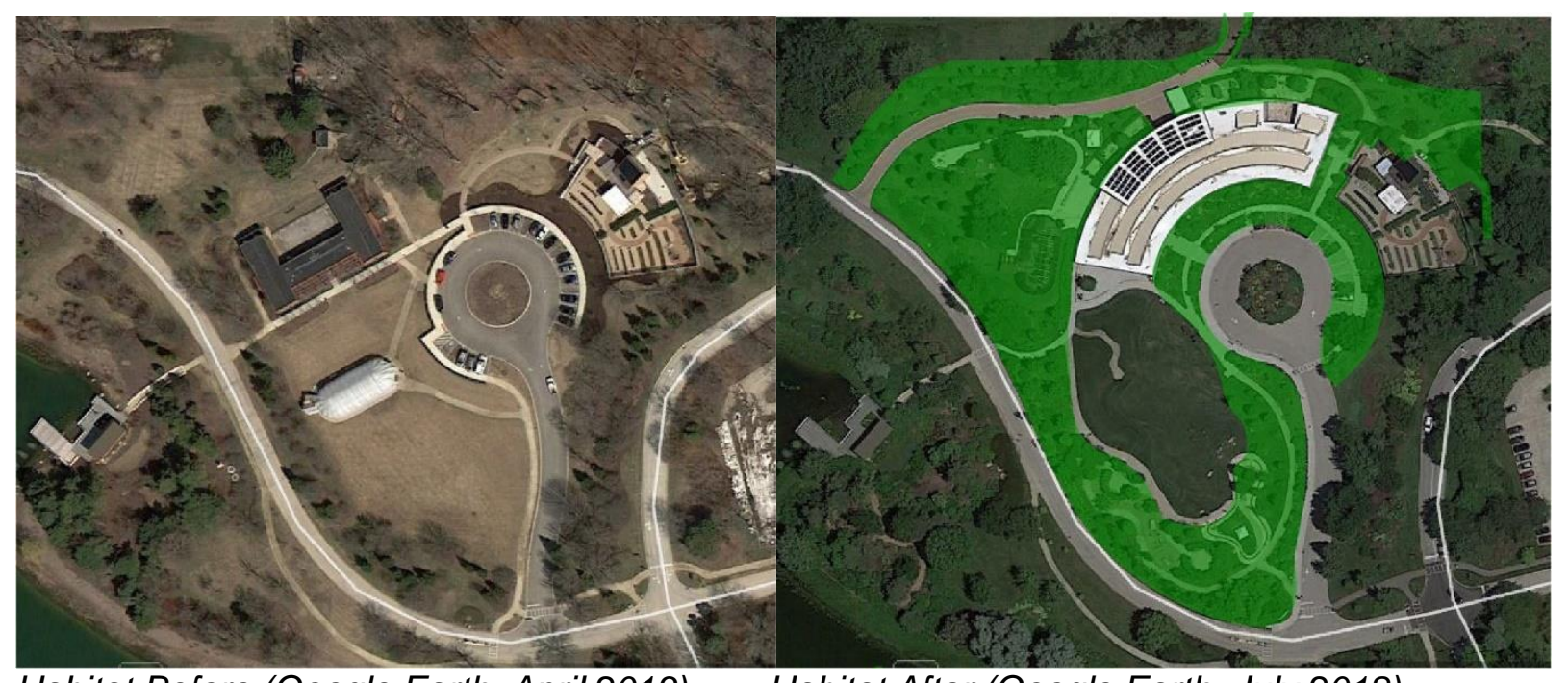

Habitat Before (Google Earth, April 2013) $\quad$ Habitat After (Google Earth, July 2018)

Methods:

Jacobs/Ryan Associates provided area calculations for the LEED 2009 SS5.1 Protect and Restore Habitat Credit, comprising existing and new native planting areas to meet and exceed the SITES required minimum that $50 \%$ of the project site be reserved for wildlife habitat. The $101,572 \mathrm{sq} f \mathrm{ft}$ of habitat equates to $52 \%$ of the project site. These metrics provided the amount of habitat area on the project site. Jacobs/Ryan also provided the calculations of the Learning Center building footprint and AutoCAD 2017 was used to perform an area takeoff from project construction drawings of the amount of habitat lost for the new service road.

A wildlife camera provided by the Urban Wildlife Institute at the Lincoln Park Zoo was tied to a tree in the Nature Play Gardens behind the Learning Center building and set to "normal" sensitivity where it took a picture when it sensed movement in its lens. The camera captured activity from June 13, to June 26, 2019. Review of the recordings captured 79 wildlife sightings, providing evidence of 11 species: chipmunk (Tamias striatus), gray squirrel (Sciurus carolinensis), white-tailed deer (Odocoileus virginianus), skunk (Mephitis mephitis), raccoon (Procyon lotor), American robin (Turdus migratorius), cottontail rabbit (Sylvilagus floridanus), European starling (Sturnus vulgaris), red-winged blackbird (Agelaius phoeniceus), grackle (Quiscalus quiscula), and house sparrows (Passer domesticus). Although many of these are common species, is it significant that the Nature Play Gardens can provide them with habitat in a suburban residential context. 


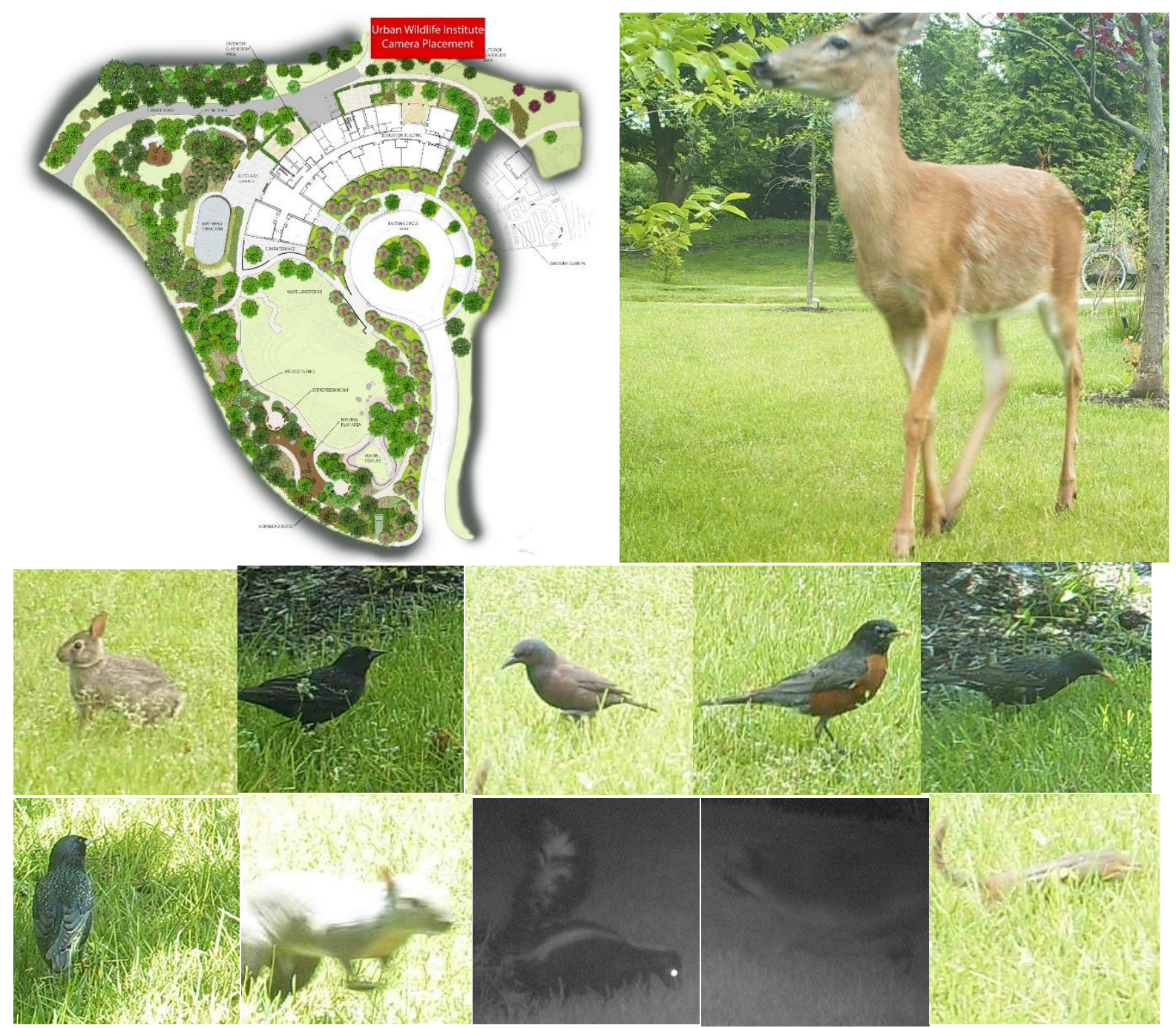

Figure 1: Images captured from camera provided by Urban Wildlife Institute, Lincoln Park Zoo, June 2019. Source: Urban Wildlife Institute

\section{Calculations:}

Protected and restored habitat and the Learning Center building footprint square footage were provided by Jacobs/Ryan Associates' SS5.1 LEED calculations document. AutoCAD provided the area of the service road from a drawing scaled to a 1:1 scale.

Habitat Lost: $18,427 \mathrm{sq} f \mathrm{ft}$ building footprint $+6,212 \mathrm{sq} \mathrm{ft}$ service road $=24,639 \mathrm{sq} \mathrm{ft}$ of lost habitat

Habitat Gained: 81,840 sf (newly added) - 24,639 sf (lost) $=$ 57,201 sf gained

Sources:

Landscape Regenstein Learning Campus Record Drawings 12-08-2016. PDF. Chicago: Jacobs/Ryan Associates, December 8, 2016.

Photos provided by Urban Wildlife Institute Camera, Chicago Botanic Garden Regenstein Learning Campus. Automated photograph by Bushnell camera. June 13-26, 2019. 
SS5.1 Calcs. Microsoft Word. Chicago: Jacobs/Ryan Associates, December 8, 2016.

\section{Limitations:}

Wildlife sightings are limited by the lens size and direction of the wildlife cameras and the limited time and seasonality of recording. It is also unknown if the wildlife observed by this research inhabited the project site prior to the project installation.

\section{Social Benefits}

- Supports engagement with the outdoors and a greater understanding of nature. $65 \%$ of 17 field trip teachers reported outdoor activities as helpful for their field trip program.

Methods: The CBG Education Department provided field trip evaluation responses from field trip teachers surveyed from 2017-2019 with teachers identifying class activities, strategies, and resources that were helpful to the field trip program. Teacher responses with keywords such as garden, planting, digging, observing, discovery, outdoor and explore were considered as responses citing use of the Nature Play Gardens. 11/17 of these responses had such keywords (Table 12).

Calculations:

\section{School Field Trip Teacher Evaluation Responses}

Q2. Please identify classroom activities, strategies, and resources that were helpful for the field trip program.

Exploration and planting

They loved the scavenger hunt and using the hand lenses

We read books and completed worksheet activities

hands on learning is the best! The children loved planting and using magnifying glasses.

The hands on learning of the planting, exploring and digging.

Hands on plant trays. Outdoor plant science observation/ sketching. Plant part search outside.

Exploring Garden, Finding Parts of plants/ seed song. Planting Sage.

The TV/board was super interactive, the magnifying glasses and insect tests were interesting.

Nice balance of time with kids being seated \& movement: getting up to act out the stages of the plant life cycle was excellent opportunity to break up the lesson with some movement.

The hands-on activities as well as the use of pictures.

Using senses to explore. Getting to plant \& take it home!

Learning about the senses. Being scientist and observing nature. 
Planting seeds, digging out/planting root vegetables. Touching \& observing pepper plants. Life cycle presentation.

The hands-on experience were great!

Planting was a great experience. The students also enjoyed acting out the plant life cycle, and arranging the picture.

Discovery \& acting our life cycle

1)Acting out life cycle 2) Planting 3) Getting to pull out plants \& replant

Table 12: School field-trip evaluation responses from teachers between 2017-2019. Source:

Chicago Botanic Garden

Sources:

School Field Trip Evaluations - Discovering Plants. Excel. Glencoe: Chicago Botanic Garden Education Department.

Limitations:

Teacher evaluation responses tallied for this metric did not include other words such as "handson", "insect tests", "movement" and "scavenger hunt" as they did not explicitly suggest outdoor participation, though they may have been outdoors, which would have strengthened this metric.

- Contributed to an estimated $30 \%$ increase in participation in drop-in educational programs between 2014 and 2018. In 2018, the Nature Play Gardens attracted 53,222 participants for 1,233 formal programs including field trips, camps, nature preschool, scouts, and family programs.

The Regenstein Learning Campus hosts a series of events annually, many of which utilize the Nature Play Gardens. Since the completion of the Nature Play Gardens, 100\% of drop-in programs in the Education Department were changed from facilitated activities to open-ended nature play activities that foster connections between families and nature. Other educational programming also utilizes the Nature Play Gardens.

Methods: The Education Department provided 2018 figures for program and participation numbers for activities specifically utilizing the Nature Play Gardens at the Regenstein Learning Campus (Table 9). These numbers were totaled to get program and participation figures for the year. Chicago Botanic Gardens (CBG) provided the total garden attendance from 1999-2018. Education programming participation for 2018 was calculated as a percentage of the 2018 CBG attendance: $5 \%$ of total CBG attendance. The department estimated the increase in drop-in programs.

\section{Calculations:}

Increase in participation in drop-in programs from 2014-2018 self-reported by the Education Department at the Chicago Botanic Gardens. Number of 2018 participants by program reported below. Total Chicago Botanic Garden attendance for 2018 is reported below for context. 


\begin{tabular}{|l|c|c|}
\hline \multicolumn{2}{|c|}{ 2018 Educational Programming in Nature Play Gardens } \\
\hline Program Type & Number of Programs & Participation per Program \\
\hline Teacher Programs & 5 & 50 \\
\hline Field Trips & 813 & 25,812 \\
\hline Camp Programs & 185 & 2,108 \\
\hline Nature Preschool & 5 & 70 \\
\hline Family Programs & 164 & 23,816 \\
\hline Scout Programs & 61 & $\mathbf{1 , 3 6 6}$ \\
\hline TOTAL & $\mathbf{1 2 3 3}$ & $\mathbf{5 3 , 2 2 2}$ \\
\hline
\end{tabular}

Total 2018 Chicago Botanic Garden Attendance

$1,045,721$

Table 9: 2018 metrics for Nature Play Garden Programs and CBG Attendance

Sources:

Chicago Botanic Garden Education Department. 2018 Educational Programming Participation Numbers. Raw data. Glencoe, Illinois.

Limitations: Raw data for the $30 \%$ increase in drop-in programs was not available to independently confirm self-reported data.

- Supports important developmental skills in children. When observed playing together through almost 4,000 observations, $27 \%$ of children demonstrated motor skills, 22\% problem-solving, 20\% risk-taking, and 15\% empathy.

Regenstein Learning Campus Nature Play Garden supports the growth of important developmental skills in children through the employment of unstructured nature play, preparing them for STEM learning and success in life.

Methods:

In July and August of 2017, Chicago Botanic Garden trained seven volunteers in observational methods based on best practices in nature play. Volunteer evaluators observed users of the Nature Play Garden making observations about the natural world, problem solving and investigation, risk-taking, using gross and fine motor skills, collaborating, using natural materials, demonstrating empathy for living things, enjoying quiet time in nature, and other nonnature play related activities. Observations were made on weekdays and weekends, morning and afternoon, at 20-minute intervals focused on specific features of the Nature Play Garden including the runnel, rolling hills, hollow logs, and willow tunnel. A total of 3,915 observations were made of primarily adult-child pairs, secondarily children together, and least observed were adults alone. Results are found in Figure 2. For all groups combined, the primary activities observed were making observations (23\%) and motor-skills activities (23\%), though they vary 
significantly by user type. Least common activities include expressing empathy for the natural world (1\%) and non-nature related activities (2\%). Exact number observed is not available.

Calculations:

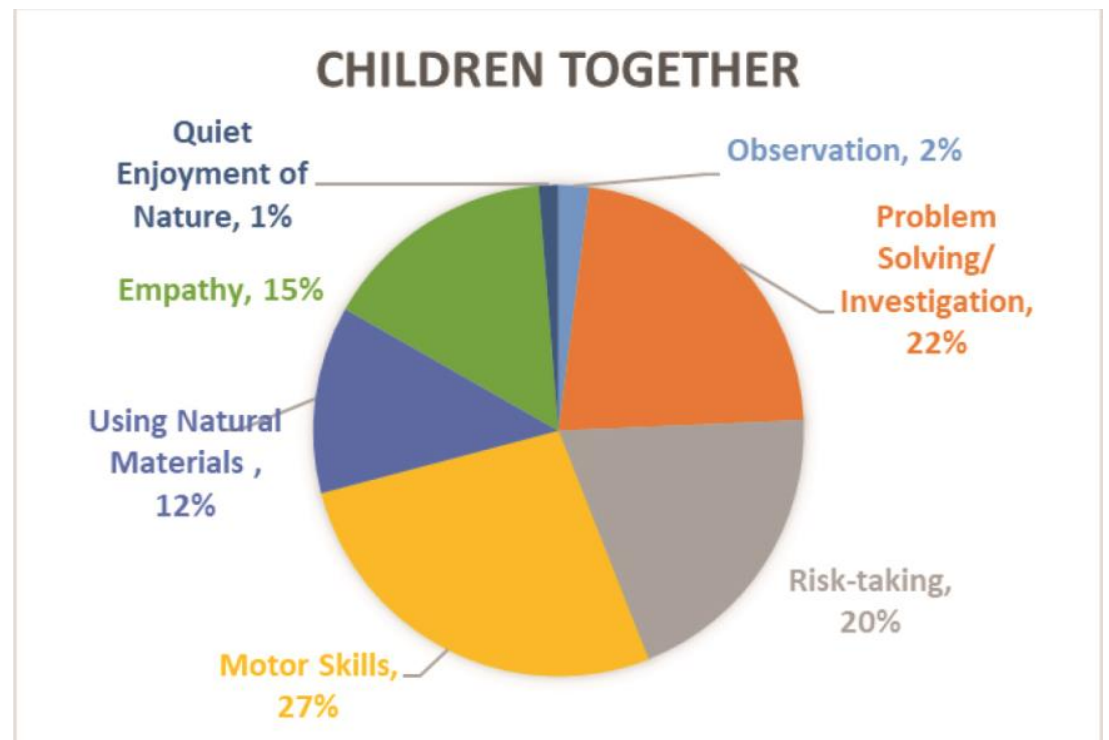

Figure 2: Observations made of children interacting together in July and August 2017. Source: Chicago Botanic Garden

Sources:

Chicago Botanic Garden Education Department. Nature Play Garden Evaluation Complete. PDF. Glencoe: Chicago Botanic Garden.

Limitations:

Not performed or independently verified by the CSI Research Team.

Additional information about program participation unrelated to landscape elements:

- Financial aid increased participation in educational programs on-site by students from schools that serve low-income populations by an estimated $72 \%$ from 20162018.

A portion of fundraising revenue generated by the Chicago Botanic Garden (CBG) was directed towards financial aid to assist in funding Title 1 school field trips at the CBG. Because of this funding, it was expected that more low-income students would be able to participate in activities at the NPG.

\section{Methods:}

To determine the percentage of low-income students participating in school field trips at the Nature Play Gardens, the CBG Education Department categorized school field trip classes into $0-24 \%, 25-49 \%, 50-74 \%, 75-89 \%, 90 \%$ or greater, or unknown regarding the percentage of students that may be categorized as low-income based on the demographics available on the 
individual schools. The number of students in each income category were tallied, which determined the percentage of the total number of students in each category (Table 12). These percentages were applied to the number of students recorded as visiting by the CBG. In 2016, 3,176 field trip students were from schools where $50 \%$ or more of the students were lowincome. In 2018, 5,486 field trip students were in the same category, an increase of 2,310 students. This increase of 2,310 was divided by the 3,176 students in 2016 to get a $72.7 \%$ increase in the number of field trip students attending schools that serve low-income populations.

\section{Calculations:}

\begin{tabular}{|r|r|r|r|r|r|r|}
\hline \multicolumn{7}{|c|}{$\begin{array}{c}\text { Categories are based on the percentage of } \\
\text { low income students at the school }\end{array}$} \\
\hline & No Data & $0-24 \%$ & $25-49 \%$ & $50-74 \%$ & $75-90 \%$ & $90 \%+$ \\
\hline $\mathbf{2 0 1 6}$ & $42 \%$ & $29 \%$ & $10 \%$ & $10 \%$ & $6 \%$ & $2 \%$ \\
\hline $\mathbf{2 0 1 7}$ & $28 \%$ & $30 \%$ & $12 \%$ & $12 \%$ & $5 \%$ & $12 \%$ \\
\hline $\mathbf{2 0 1 8}$ & $31 \%$ & $24 \%$ & $17 \%$ & $9 \%$ & $7 \%$ & $12 \%$ \\
\hline
\end{tabular}

Table 12: Student financial demographics. Source: Chicago Botanic Gardens

Increase in low-income students: (5,486 students $-3,176$ students) $=2,310$ student increase / 3,176 students $=.73 \times 100=73 \%$

Sources:

Chicago Botanic Gardens Education Department. Field Trip Demographics Over Time. Raw data. Chicago Botanic Garden, Glencoe.

Limitations:

Data was not available for $31 \%$ of field trip students in 2018 and $42 \%$ of students in 2018 . Exact numbers of students were not available.

\section{Economic Benefits}

- Created 1 full-time and 6 seasonal teaching positions along with 1 part-time maintenance position.

Teaching positions were added in anticipation of the Regenstein Learning Campus programs. There is now 1 full-time year-round position, the Early Childhood Programs Manager \& Nature Preschool Director, and 3 seasonal lead teachers and 3 seasonal assistant teachers (2 lead teachers are full time and the rest of teachers are all part time; all of these teachers work September through May)

Methods: The Chicago Botanic Garden (CBG) Education Department provided the numbers of positions added for the campus programs, all of the positions of which operate within the Nature Play Gardens as part of their job description. 
Calculations:

Data reported by the CBG Education Department and the Executive Vice President and Director.

Sources:

Chicago Botanic Garden Education Department. Positions Added for Regenstein Learning Campus. Raw data. Chicago Botanic Garden, Glencoe.

Limitations:

Not all teaching responsibilities take place in the Nature Play Gardens, but all occur on the Regenstein Learning Campus.

- Generated \$2.25 million in capital funds and catalyzed over \$130,000 in scholarships for youth education, part of which supported 15 student scholarships for free or reduced-cost camp and Nature Preschool sessions.

Methods: The Executive Vice President and Director of the Chicago Botanic Gardens provided the amounts for capital funds raised dedicated specifically to areas in the Nature Play Garden and raised for youth education. Funds raised for youth education were used for financial aid for Title 1 schools, 10 full scholarships for students to attend 15 camp sessions, and 5 students to attend Nature Preschool at a reduced cost or free of charge.

Calculations:

Data reported by the Chicago Botanic Garden Executive Vice President and Director.

Sources:

Chicago Botanic Garden Administration. Capital funds raised for Nature Play Garden. Raw data. Chicago Botanic Garden, Glencoe.

Limitations:

The exact amount of funds received for individual components of youth education (camp scholarships, Nature Preschool cost of attendance, etc.) were not provided.

\section{Additional Benefits: Nature Preschool}

- Increases the amount of time families spend outside per week through the Nature Preschool as reported by $59 \%$ of 41 surveyed parents. $27 \%$ of 33 surveyed parents visit the Nature Play Gardens 1-3 times per week.

The Nature Play Gardens is unique at the Chicago Botanic Gardens (CBG) as an open recreational space for adults and children to engage with nature informally. Prior to the construction of the Regenstein Learning Campus and Nature Play Gardens (NPG), for example, 
children would spend less time in the garden before and after classes because there was not an open play space at the CBG. $100 \%$ of parents surveyed chose Nature Preschool for their children because of the outdoor experiences.

Methods: The CBG Education Department surveyed parents of Nature Preschool participants after the 2018-2019 school year. When asked how much time they spent outside as a family before and after their child attending Nature Preschool, 24/41, or 59\%, of parents self-reported more hours spent outside. In the same survey, when aked what factors helped them select Nature Preschool, 41/41, or $100 \%$ selected "outdoor experiences" (Table 10). In a separate survey distributed to parents by the CSI Research Team on June 19 and July 17, 2019, parents were asked how often they visit the NPG, 9/33, or 27\%, reporting that they visit 1-3 times per week (Table 11). The complete CSI survey is found in Appendix A.

Calculations:

\begin{tabular}{|l|r|r|}
\hline Which factors helped you select Nature Preschool? & 6 & $14.63 \%$ \\
\hline Fee & 15 & $36.58 \%$ \\
\hline Distance from your home & 13 & $31.70 \%$ \\
\hline Attended prior CBG programs & 16 & $39.02 \%$ \\
\hline Reputation of the program & 41 & $100 \%$ \\
\hline Outdoor experiences & 6 & $14.63 \%$ \\
\hline Licensing & 23 & $56.09 \%$ \\
\hline Quality of teachers & 10 & $24.39 \%$ \\
\hline Member discount on registration & 24 & $58.54 \%$ \\
\hline Increase in amount of time family spent outside per week & 17 & $41.46 \%$ \\
\hline Yes & $41 / 41$ & \\
\hline No & 24 & \\
\hline
\end{tabular}

Table 10: Program Evaluation for Nature Preschool 2018-2019. Source: Chicago Botanic Garden

3. How often do you visit the Regenstein Learning Campus Nature Play Garden and outdoor classrooms at the Chicago Botanic Garden? (Please circle one of the following)

\begin{tabular}{|l|r|r|}
\hline First time & 10 & $30.30 \%$ \\
\hline 1 to 3 times per week & 9 & $27.27 \%$ \\
\hline 1 to 3 times per month & 6 & $18.18 \%$ \\
\hline 1 to 3 times per season & 6 & $18.18 \%$ \\
\hline 1 to 3 times per year & 2 & $6.06 \%$ \\
\hline & $33 / 33$ & \\
\hline
\end{tabular}


Table 11: Frequency of visitation as self-reported on June 19 and July 17, 2019. Source: CSI Research Team

Sources:

Callone, Matt. Regenstein Learning Campus User Survey. July 17, 2019. Raw data. Regenstein Learning Campus, Glencoe.

Education Department. Program Evaluation-Nature Preschool 2018-2019. June, 2019. Raw data. Regenstein Learning Campus, Glencoe.

Limitations: There was no clear majority of visitation frequency to the NPG as self-reported in the Regenstein Learning Campus User Survey. Bias may be assumed in surveying just parents who participate in CBG programs.

- $34 \%$ of 41 surveyed parents whose children participated in Nature Preschool programming reported that their child has seen the greatest development in their "love for," "knowledge of," or "understanding of" the natural world.

Methods: The CBG Education Department surveyed parents of Nature Preschool participants after the 2018-2019 school year. When asked what areas they have seen the greatest development or growth in their child, 14/41, or 34\%, responded with answers expressing that their child has a greater "love", "knowledge" or "understanding" of the "natural world" or "nature". "What areas have you seen the greatest development or growth in your child?"

Question asked in Program Evaluation for Nature Preschool after 2018-2019 school year.

Sources:

Education Department. Program Evaluation-Nature Preschool 2018-2019. June, 2019. Raw data. Regenstein Learning Campus, Glencoe.

Limitations:

Parent responses tallied for the Program Evaluation for Nature Preschool consisting of "outdoors" or "outside" were not included as they did not explicitly mention nature and have less correlation to the Nature Play Gardens. 


\section{Appendix A:}

Regenstein Learning Campus Visitor Survey

\section{Regenstein Learning Campus Visitor Survey}

1. Are you a member of the Chicago Botanic Garden?
a. Yes (Please circle one of the following)
i. Garden Plus member
ii. Garden member
iii. Educator Garden member
iv. National Garden member
v. Not sure

b. No

2. How often do you visit the Chicago Botanic Garden? (Please circle one of the following)
a. First time
b. 1 to 3 times per week
c. 1 to 3 times per month
d. 1 to 3 times per season
e. 1 to 3 times per year

3. How often do you visit the Regenstein Learning Campus Nature Play Garden and outdoor classrooms at the Chicago Botanic Garden? (Please circle one of the following)
a. First time
b. 1 to 3 times per week
c. 1 to 3 times per month
d. 1 to 3 times per season
e. 1 to 3 times per year

4. Would you visit the Chicago Botanic Garden if the Regenstein Learning Campus Nature Play Garden did not exist?
a. Yes
b. No

5. Do you have a child or children enrolled in Nature Preschool at the Chicago Botanic Garden?
a. Yes
b. No

6. Does your child talk about the Nature Play Garden and/or Nature Preschool at home? If so, please describe what your child says about the Nature Play Garden and/or Nature Preschool. 
7. When visiting the Chicago Botanic Garden, how much time do you generally spend at the Nature Play Garden?

a. 30 minutes or less

b. 31 minutes to 60 minutes

c. 1 hour to 2 hours

d. 2 hours to 3 hours

e. More than 3 hours

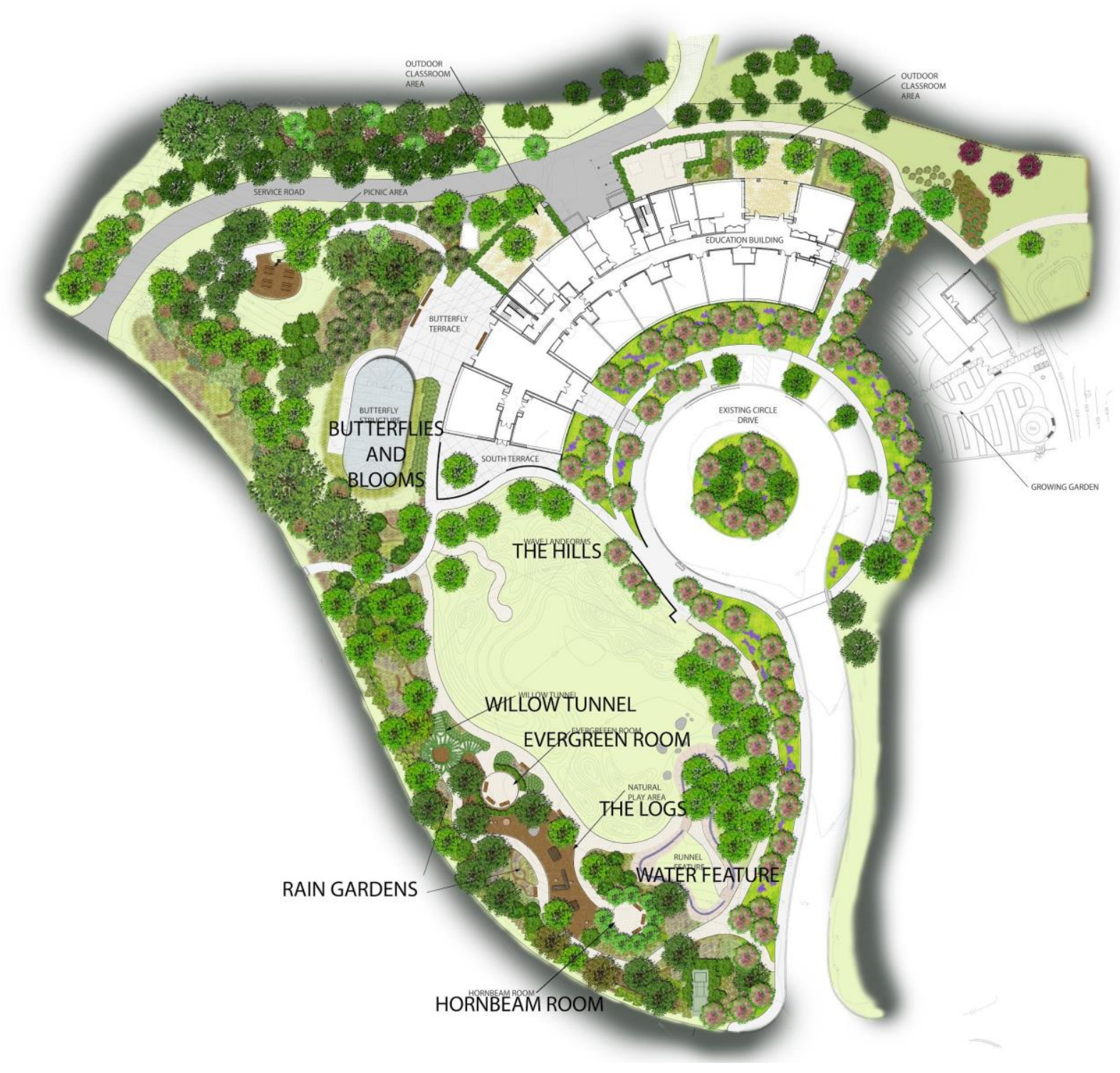


8. When in the Nature Play Garden, what are your top 3 areas to spend time in? (Complete for both adults and children if applicable. List in order of preference with 1 as your favorite. Refer to diagram on the previous page.)

\section{Adult Users}

Willow Tunnel

The Logs

Water Feature

The Hills

Butterflies and Blooms

Evergreen Room

Hornbeam Room

Rain Gardens

\section{Child Users}

Willow Tunnel

The Logs

Water Feature

The Hills

Butterflies and Blooms Evergreen Room Hornbeam Room Rain Gardens

9. Please rank your reasons for visiting the Regenstein Learning Campus Nature Play Garden and outdoor classrooms today? (Please list your primary reason as 1 and 6 as lowest reason)

To play and get exercise outside

To learn in Nature Preschool

To learn informally and play creatively in nature

To get together with friends

To explore nature

To feel restored

Other, please describe:

10. Do you go to other parts of the Learning Campus before or after visiting the Nature Play Garden and outdoor classrooms? (Please select all that apply)

a. I often go to the Kleinman Family Cove.

b. I often go to the Grunsfeld Children's Growing Garden.

c. I sometimes go to the Kleinman Family Cove.

d. I sometimes go to the Grunsfeld Children's Growing Garden.

e. No, I do not go to other parts of the Learning Campus.

11. If you didn't visit the Learning Campus Nature Play Garden today, where would you have gone instead?

a. A park in my neighborhood

b. A community center

c. A playground

d. Lake Michigan lakefront park 
e. Stayed at home

f. Other, please describe:

12. Please rank the statements below based on your opinion. (Please rank all that apply with 1 being most important)

The Nature Play Garden provides me and/or my child opportunities for physical exercise that we would not have access to elsewhere.

The Nature Play Garden provides me and/or my child opportunities to experience nature that we would not have access to elsewhere.

The Nature Play Garden provides me and/or my child opportunities to have free play outdoors that we would not have access to elsewhere.

The Learning Campus and Nature Play Garden provides me and/or my child opportunities to take a class or camp that we would not have access to elsewhere. None of the above.

\section{Appendix B:}

Full Report - Nature Play Gardens Before Condition FQI (not reported in Benefits)

\begin{tabular}{|c|c|c|c|}
\hline \multicolumn{4}{|c|}{ Nature Play Gardens - Former Conditions } \\
\hline \multicolumn{4}{|c|}{\begin{tabular}{|r|r|}
$6 / 24 / 2019$ & \\
\end{tabular}} \\
\hline Nature Play Gardens & Glencoe & Cook & Illnois \\
\hline \multicolumn{4}{|c|}{\begin{tabular}{|l|l|} 
United States & \\
\end{tabular}} \\
\hline FQA DB Region: & \multicolumn{3}{|c|}{ Chicago Region USACE } \\
\hline $\begin{array}{l}\text { FQA DB Publication } \\
\text { Year: }\end{array}$ & \multicolumn{2}{|l|}{2017} & \\
\hline \multicolumn{4}{|c|}{ FQA DB Description: https://www.Irc.usace.army.mil/Missions/Regulatory/FQA.aspx } \\
\hline Practitioner: & \multicolumn{3}{|c|}{ Matt Callone } \\
\hline Latitude: & 42.151406 & & \\
\hline Longitude: & -87.791315 & & \\
\hline Private/Public: & Private & & \\
\hline \multicolumn{4}{|c|}{ Conservatism-Based Metrics: } \\
\hline Total Mean C: & 2.8 & & \\
\hline Native Mean C: & 4.8 & & \\
\hline Total FQI: & 13.1 & & \\
\hline Native FQI: & 17.3 & & \\
\hline Adjusted FQI: & 36.9 & & \\
\hline$\%$ C value $0:$ & 45.5 & & \\
\hline$\%$ C value 1-3: & 18.2 & & \\
\hline$\%$ C value 4-6: & 18.2 & & \\
\hline
\end{tabular}


$\%$ C value 7-10:

Native Tree Mean C:

Native Shrub Mean

C:

Native Herbaceous

Mean C:

\section{Species Richness:}

Total Species:

Native Species:

Non-native Species:

Species Wetness:

Mean Wetness:

Native Mean

Wetness:

Physiognomy Metrics:

Tree:

Shrub:

Vine:

Forb:

Grass:

Sedge:

Rush:

Fern:

Bryophyte:

\section{Duration Metrics:}

Annual:

Perennial:

Biennial:

Native Annual:

Native Perennial:

Native Biennial:

\section{Species:}

\begin{tabular}{|c|c|c|c|c|c|c|}
\hline Scientific Name & Family & Native? & C V & \begin{tabular}{l|l} 
Physiognom \\
w
\end{tabular} & Duration & Common Name \\
\hline Acer campestre & Aceraceae & $\begin{array}{l}\text { non- } \\
\text { native }\end{array}$ & 0 & 2 tree & perennial & hedge maple \\
\hline Acer saccharinum & Aceraceae & native & 1 & 1 tree & perennial & silver maple \\
\hline Acer $x$ freemanii & Aceraceae & native & 0 & 2 tree & perennial & freemans maple \\
\hline Catalpa speciosa & Bignoniaceae & $\begin{array}{l}\text { non- } \\
\text { native }\end{array}$ & 0 & 1 tree & perennial & northern catalpa \\
\hline \begin{tabular}{|l} 
Cercidiphyllum \\
japonicum
\end{tabular} & $\begin{array}{l}\text { Cercidiphyllace } \\
\text { ae }\end{array}$ & $\begin{array}{l}\text { non- } \\
\text { native }\end{array}$ & 0 & 2 tree & perennial & katsura tree \\
\hline
\end{tabular}

18.2

4.8

$n / a$

$n / a$

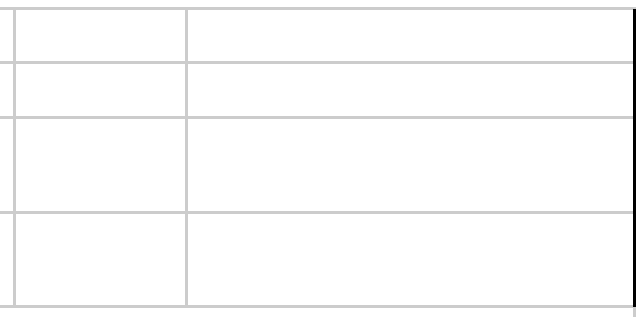

22

$1359.10 \%$

$940.90 \%$

\begin{tabular}{r|r|r|}
\hline 1 & \\
\hline 0.6 & \\
\hline
\end{tabular}

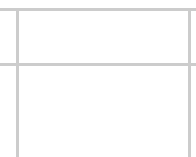

\begin{tabular}{|r|r|r|r|r|r|}
\hline 21 & $95.50 \%$ & & & \\
\hline 1 & $4.50 \%$ & & & \\
\hline 0 & $0 \%$ & & & \\
\hline 0 & $0 \%$ & & & \\
\hline 0 & $0 \%$ & & & \\
\hline 0 & $0 \%$ & & & \\
\hline 0 & $0 \%$ & & & \\
\hline 0 & $0 \%$ & & & & \\
\hline
\end{tabular}
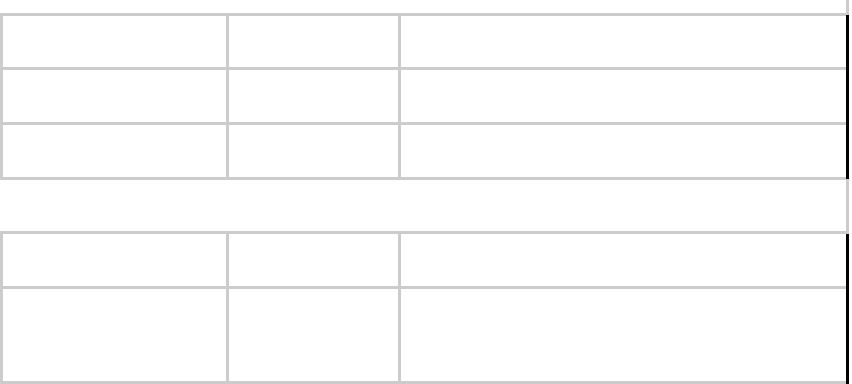

| I t

\begin{tabular}{|r|r|l|l|l|l|}
\hline 0 & $0 \%$ & & & \\
\hline 22 & $100 \%$ & & & \\
\hline 0 & $0 \%$ & & & \\
\hline 0 & $0 \%$ & & & \\
\hline 13 & $59.10 \%$ & & & \\
\hline 0 & $0 \%$ & & & \\
\hline
\end{tabular}




\begin{tabular}{|c|c|c|c|c|c|c|}
\hline $\begin{array}{l}\text { Crataegus } \\
\text { chrysocarpa }\end{array}$ & Rosaceae & native & 4 & 2 tree & perennial & fireberry hawthorn \\
\hline Crataegus crus-galli & Rosaceae & native & 3 & 0 ftree & perennial & cock-spur hawthorn \\
\hline \begin{tabular}{|l|} 
Fraxinus \\
pennsylvanica
\end{tabular} & Oleaceae & native & 4 & 1 tree & perennial & green ash \\
\hline Ginkgo biloba & Ginkgoaceae & $\begin{array}{l}\text { non- } \\
\text { native }\end{array}$ & 0 & 2 tree & perennial & ginkgo \\
\hline Gleditsia triacanthos & Fabaceae & native & 1 & 1 tree & perennial & honey-locust \\
\hline Gymnocladus dioicus & $\begin{array}{l}\text { Caesalpiniacea } \\
\text { e }\end{array}$ & native & 8 & 2 tree & perennial & kentucky coffee tree \\
\hline Magnolia stellata & Magnoliaceae & $\begin{array}{l}\text { non- } \\
\text { native }\end{array}$ & 0 & 2 tree & perennial & star magnolia \\
\hline Malus baccata & Rosaceae & $\begin{array}{l}\text { non- } \\
\text { native }\end{array}$ & 0 & 2 tree & perennial & siberian crab apple \\
\hline \begin{tabular}{|l} 
Philadelphus \\
coronarius
\end{tabular} & Philadelphacea & $\begin{array}{l}\text { non- } \\
\text { native }\end{array}$ & 0 & 2 shrub & perennial & sweet mock orange \\
\hline Picea abies & Pinaceae & $\begin{array}{l}\text { non- } \\
\text { native }\end{array}$ & 0 & 2 tree & perennial & norway spruce \\
\hline Pinus resinosa & Pinaceae & native & \begin{tabular}{|l|} 
\\
0 \\
\end{tabular} & 1 tree & perennial & red pine \\
\hline Populus tremuloides & Salicaceae & native & 3 & 0 tree & perennial & quaking aspen \\
\hline Quercus lyrata & Fagaceae & $\begin{array}{l}\text { non- } \\
\text { native }\end{array}$ & 0 & 2 tree & perennial & overcup oak \\
\hline Quercus macrocarpa & Fagaceae & native & 5 & 0 tree & perennial & burr oak \\
\hline $\begin{array}{l}\text { Quercus } \\
\text { muhlenbergii }\end{array}$ & Fagaceae & native & 8 & 1 tree & perennial & chinkapin oak \\
\hline Quercus velutina & Fagaceae & native & 5 & 2 tree & perennial & black oak \\
\hline Thuja occidentalis & Cupressaceae & native & $\begin{array}{l}1 \\
0\end{array}$ & 1 tree & perennial & eastern arborvitae \\
\hline
\end{tabular}

\section{Appendix C:}

Full Report - Nature Play Gardens 2019 Plant List and FQI (not reported in Benefits)

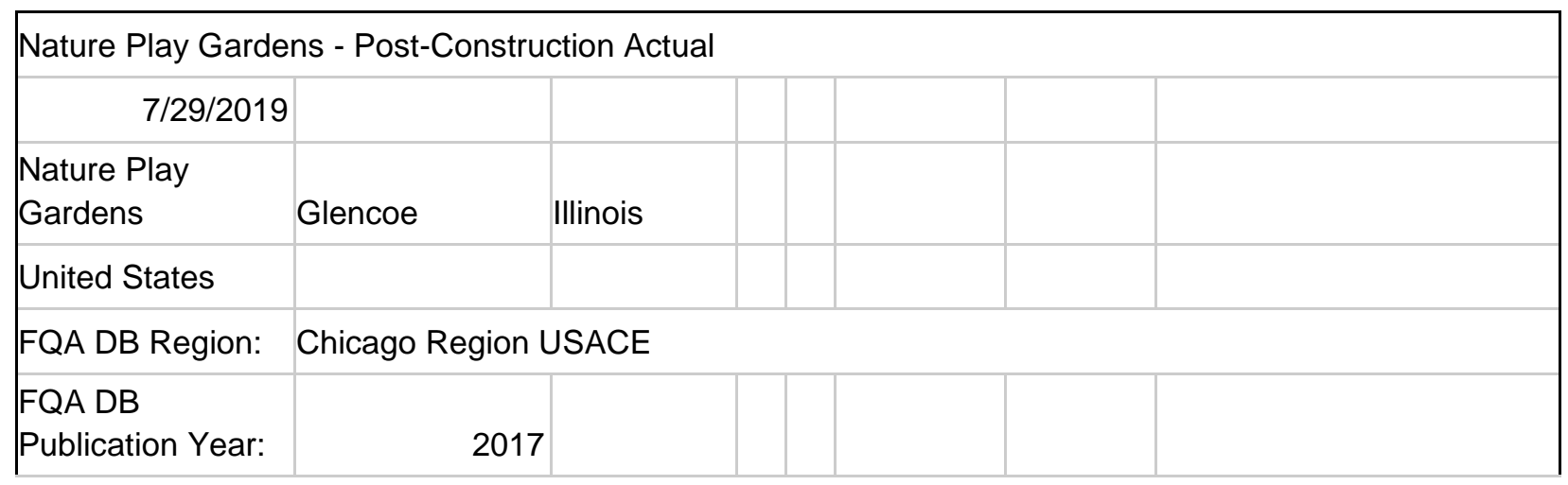




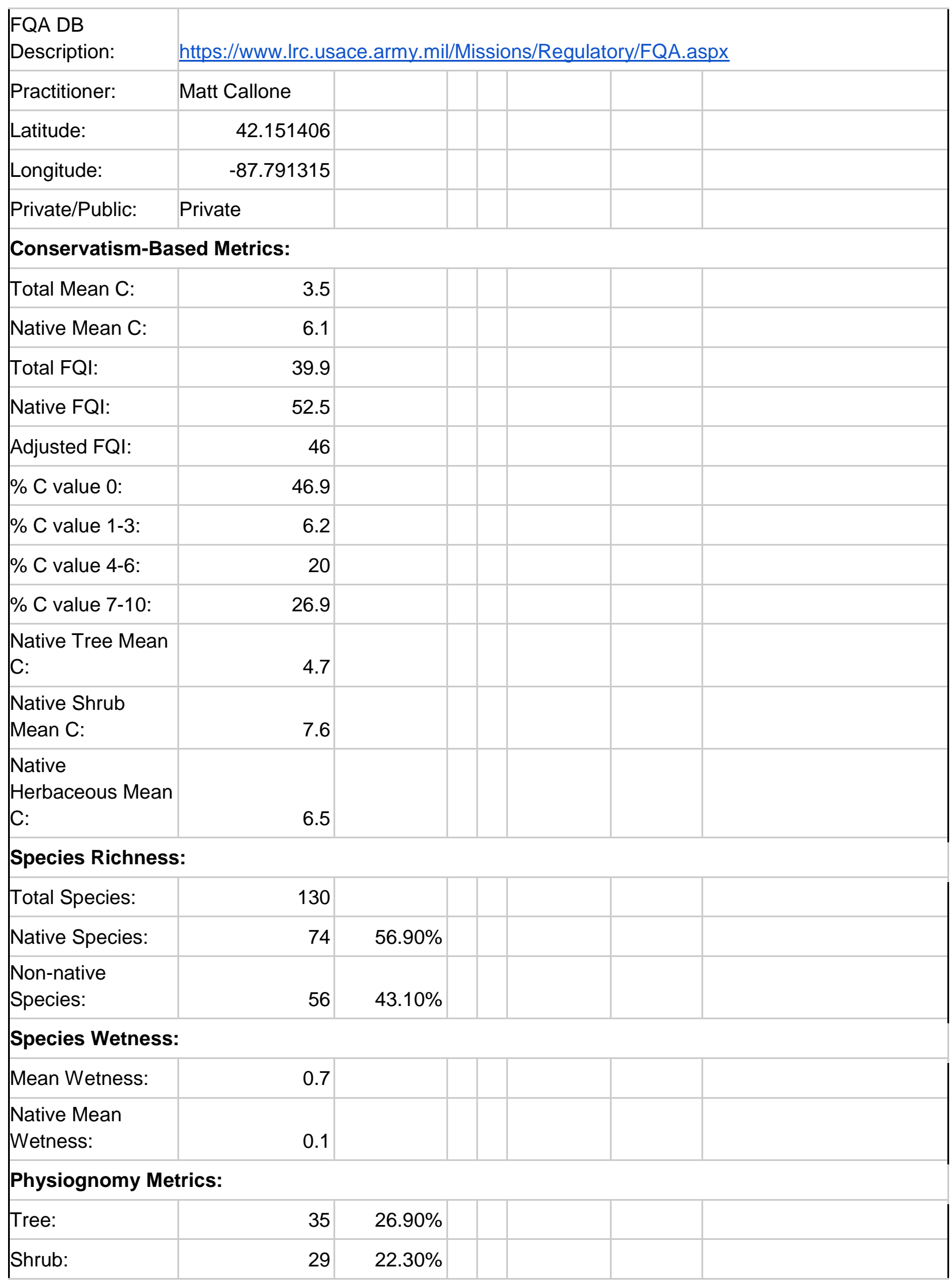




\begin{tabular}{|c|c|c|c|c|c|c|}
\hline Vine: & 3 & $2.30 \%$ & & & & \\
\hline Forb: & 52 & $40 \%$ & & & & \\
\hline Grass: & 8 & $6.20 \%$ & & & & \\
\hline Sedge: & 0 & $0 \%$ & & & & \\
\hline Rush: & 0 & $0 \%$ & & & & \\
\hline Fern: & 3 & $2.30 \%$ & & & & \\
\hline Bryophyte: & 0 & $0 \%$ & & & & \\
\hline \multicolumn{7}{|l|}{ Duration Metrics: } \\
\hline Annual: & 4 & $3.10 \%$ & & & & \\
\hline Perennial: & 125 & $96.20 \%$ & & & & \\
\hline Biennial: & 1 & $0.80 \%$ & & & & \\
\hline Native Annual: & 2 & $1.50 \%$ & & & & \\
\hline Native Perennial: & 71 & $54.60 \%$ & & & & \\
\hline Native Biennial: & 1 & $0.80 \%$ & & & & \\
\hline \multicolumn{7}{|l|}{ Species: } \\
\hline Scientific Name & Family & Native? & c & \begin{tabular}{l|l} 
Whysiogn & $\begin{array}{l}\text { omy } \\
\text { omy }\end{array}$
\end{tabular} & Duration & Common Name \\
\hline Acer rubrum & Aceraceae & native & 5 & 0 tree & perennial & red maple \\
\hline Acer saccharum & Aceraceae & native & 5 & 1 tree & perennial & sugar maple \\
\hline Acer $x$ freemanii & Aceraceae & native & 0 & 2 tree & perennial & freemans maple \\
\hline Actaea pachypoda & Ranunculaceae & native & 8 & 1 forb & perennial & white baneberry \\
\hline Adiantum pedatum & n Pteridaceae & native & 0 & 1 fern & perennial & northern maidenhair \\
\hline $\begin{array}{l}\text { Agastache } \\
\text { foeniculum }\end{array}$ & Lamiaceae & native & 0 & 2 forb & perennial & blue giant-hyssop \\
\hline Ajuga reptans & Lamiaceae & non-native & 0 & 2 forb & perennial & carpet bugleweed \\
\hline Allium aflatunense & Liliaceae & native & 0 & 2 forb & perennial & ornamental onion \\
\hline $\begin{array}{l}\text { Amelanchier } \\
\text { alnifolia }\end{array}$ & Rosaceae & non-native & 0 & 1 shrub & perennial & saskatoon service-berry \\
\hline $\begin{array}{l}\text { Amelanchier x } \\
\text { grandiflora }\end{array}$ & Rosaceae & non-native & 0 & 2 shrub & perennial & sweet-fruited service-berry \\
\hline $\begin{array}{l}\text { Andropogon } \\
\text { gerardii }\end{array}$ & Poaceae & native & 5 & 0 grass & perennial & big bluestem \\
\hline $\begin{array}{l}\text { Anemone } \\
\text { canadensis }\end{array}$ & Ranunculaceae & native & 4 & -1 forb & perennial & round-leaf thimbleweed \\
\hline
\end{tabular}




\begin{tabular}{|c|c|c|c|c|c|c|}
\hline $\begin{array}{l}\text { Aronia } \\
\text { melanocarpa }\end{array}$ & Rosaceae & native & 7 & -1 shrub & perennial & black chokeberry \\
\hline Aruncus dioicus & Rosaceae & native & 0 & 1 forb & perennial & goats beard \\
\hline $\begin{array}{l}\text { Asarum } \\
\text { canadense }\end{array}$ & Aristolochiaceae & native & $\begin{array}{l}1 \\
0\end{array}$ & 1 forb & perennial & canadian wild ginger \\
\hline Baptisia australis & Fabaceae & non-native & 0 & 1 forb & perennial & blue wild indigo \\
\hline Betula pendula & Betulaceae & non-native & 0 & 2 tree & perennial & european weeping birch \\
\hline Bouteloua gracilis & Poaceae & non-native & 0 & 2 grass & perennial & blue grama \\
\hline $\begin{array}{l}\text { Buxus } \\
\text { sempervirens }\end{array}$ & Buxaceae & non-native & 0 & 2 shrub & perennial & boxwood \\
\hline $\begin{array}{l}\text { Camassia } \\
\text { scilloides }\end{array}$ & Liliaceae & native & 7 & 0 forb & perennial & atlantic camas \\
\hline Campsis radicans & Bignoniaceae & non-native & 0 & 1 vine & perennial & trumpet-creeper \\
\hline $\begin{array}{l}\text { Carpinus } \\
\text { caroliniana ssp. } \\
\text { virginiana }\end{array}$ & Betulaceae & native & 8 & 0 tree & perennial & american hornbeam \\
\hline $\begin{array}{l}\text { Cephalanthus } \\
\text { occidentalis }\end{array}$ & Rubiaceae & native & 5 & -2 shrub & perennial & common buttonbush \\
\hline $\begin{array}{l}\text { Cercidiphyllum } \\
\text { japonicum }\end{array}$ & $\begin{array}{l}\text { Cercidiphyllacea } \\
\text { e }\end{array}$ & non-native & 0 & 2 tree & perennial & katsura tree \\
\hline Cercis canadensis & Fabaceae & native & 5 & 1 tree & perennial & redbud \\
\hline Chelone glabra & $\begin{array}{l}\text { Scrophulariacea } \\
\text { e }\end{array}$ & native & 8 & -2 forb & perennial & white turtlehead \\
\hline $\begin{array}{l}\text { Chelone obliqua } \\
\text { var. speciosa }\end{array}$ & $\begin{array}{l}\text { Scrophulariacea } \\
\text { e }\end{array}$ & non-native & 0 & -2 forb & perennial & red turtlehead \\
\hline Clematis glauca & Ranunculaceae & non-native & 0 & 2 vine & perennial & yellow bell clamatis \\
\hline $\begin{array}{l}\text { Clematis } \\
\text { integrifolia }\end{array}$ & Ranunculaceae & non-native & 0 & 2 vine & perennial & blue virgins-bower \\
\hline $\begin{array}{l}\text { Conoclinium } \\
\text { coelestinum }\end{array}$ & Asteraceae & non-native & 0 & -1 forb & perennial & blue mistflower \\
\hline Coreopsis basalis & Asteraceae & non-native & 0 & 2 forb & annual & golden wave \\
\hline Cornus alba & Cornaceae & native & 5 & -1 shrub & perennial & red osier \\
\hline Cornus mas & Cornaceae & non-native & 0 & 2 tree & perennial & cornelian cherry \\
\hline Cornus obliqua & Cornaceae & native & 5 & -1 shrub & perennial & pale dogwood \\
\hline Cotinus coggygria & Anacardiaceae & non-native & 0 & 2 shrub & perennial & european smoke-tree \\
\hline $\begin{array}{l}\text { Crataegus crus- } \\
\text { galli }\end{array}$ & Rosaceae & native & 3 & 0 tree & perennial & cock-spur hawthorn \\
\hline
\end{tabular}




\begin{tabular}{|c|c|c|c|c|c|c|}
\hline $\begin{array}{l}\text { Crataegus } \\
\text { phaenopyrum }\end{array}$ & Rosaceae & non-native & 0 & 0 tree & perennial & washington hawthorn \\
\hline $\begin{array}{l}\text { Crocus } \\
\text { chrysanthus }\end{array}$ & Iridaceae & non-native & 0 & 2 forb & perennial & golden crocus \\
\hline $\begin{array}{l}\text { Dasiphora } \\
\text { fruticosa }\end{array}$ & Rosaceae & native & $\begin{array}{l}1 \\
0\end{array}$ & -1 shrub & perennial & golden-hardhack \\
\hline $\begin{array}{l}\text { Deschampsia } \\
\text { caespitosa }\end{array}$ & Poaceae & native & $\begin{array}{l}1 \\
0\end{array}$ & -1 grass & perennial & tufted hair grass \\
\hline Deutzia scabra & Philadelphaceae & non-native & 0 & 2 shrub & perennial & fuzzy pride-of-rochester \\
\hline \begin{tabular}{|l} 
Dicentra \\
canadensis
\end{tabular} & Fumariaceae & native & 8 & 2 forb & perennial & squirrel corn \\
\hline Diervilla lonicera & Caprifoliaceae & native & $\begin{array}{l}1 \\
0\end{array}$ & 2 shrub & perennial & dwarf honeysuckle \\
\hline $\begin{array}{l}\text { Diospyros } \\
\text { virginiana }\end{array}$ & Ebenaceae & non-native & 0 & 0 tree & perennial & common persimmon \\
\hline $\begin{array}{l}\text { Dodecatheon } \\
\text { meadia }\end{array}$ & Primulaceae & native & 6 & 1 forb & perennial & pride-of-ohio \\
\hline $\begin{array}{l}\text { Dryopteris } \\
\text { carthusiana }\end{array}$ & Dryopteridaceae & native & 8 & -1 fern & perennial & spinulose wood fern \\
\hline $\begin{array}{l}\text { Dryopteris } \\
\text { intermedia }\end{array}$ & Dryopteridaceae & native & 9 & 0 fern & perennial & evergreen wood fern \\
\hline Echinacea pallida & Asteraceae & native & $\begin{array}{l}1 \\
0\end{array}$ & 2 forb & perennial & pale conefower \\
\hline $\begin{array}{l}\text { Eupatorium } \\
\text { perfoliatum }\end{array}$ & Asteraceae & native & 4 & -2 forb & perennial & common boneset \\
\hline Fagus grandifolia & Fagaceae & native & 5 & 1 tree & perennial & american beech \\
\hline Filipendula ulmaria & Rosaceae & non-native & 0 & -1 forb & perennial & queen-of-the-meadow \\
\hline $\begin{array}{l}\text { Forsythia } \\
\text { suspensa }\end{array}$ & Oleaceae & non-native & 0 & 2 shrub & perennial & |japanese golden bell \\
\hline $\begin{array}{l}\text { Fraxinus } \\
\text { americana }\end{array}$ & Oleaceae & native & 5 & 1 tree & perennial & white ash \\
\hline $\begin{array}{l}\text { Fraxinus } \\
\text { pennsylvanica }\end{array}$ & Oleaceae & native & 4 & -1 tree & perennial & green ash \\
\hline $\begin{array}{l}\text { Geranium } \\
\text { bicknellii }\end{array}$ & Geraniaceae & native & 4 & 2 forb & annual & northern cranesbill \\
\hline Geum aleppicum & Rosaceae & native & 3 & -1 forb & perennial & yellow avens \\
\hline Ginkgo biloba & Ginkgoaceae & non-native & 0 & 2 tree & perennial & ginkgo \\
\hline $\begin{array}{l}\text { Gleditsia } \\
\text { triacanthos }\end{array}$ & Fabaceae & native & 1 & 1 tree & perennial & honey-locust \\
\hline
\end{tabular}




\begin{tabular}{|c|c|c|c|c|c|c|}
\hline $\begin{array}{l}\text { Gymnocladus } \\
\text { dioicus }\end{array}$ & Caesalpiniaceae & native & 8 & 2 tree & perennial & kentucky coffee tree \\
\hline $\begin{array}{l}\text { Hamamelis } \\
\text { virginiana }\end{array}$ & Hamamelidacea & native & 8 & 1 shrub & perennial & american witch-hazel \\
\hline Helenium amarum & Asteraceae & non-native & 0 & 1 forb & annual & yellowdicks \\
\hline Hemerocallis fulva & Liliaceae & non-native & 0 & 2 forb & perennial & orange day-lily \\
\hline $\begin{array}{l}\text { Heuchera } \\
\text { americana }\end{array}$ & Saxifragaceae & native & $\begin{array}{l}1 \\
0\end{array}$ & 1 forb & perennial & american alumroot \\
\hline Hibiscus laevis & Malvaceae & native & 7 & -2 forb & perennial & halberd-leaf rose-mallow \\
\hline $\begin{array}{l}\text { Hibiscus } \\
\text { moscheutos }\end{array}$ & Malvaceae & native & 7 & -2 forb & perennial & crimson-eyed rose-mallow \\
\hline $\begin{array}{l}\text { Hyacinthoides } \\
\text { non-scripta }\end{array}$ & Hyacinthaceae & non-native & 0 & 2 forb & perennial & english bluebell \\
\hline $\begin{array}{l}\text { Hydrangea } \\
\text { arborescens }\end{array}$ & Hydrangeaceae & native & $\begin{array}{l}1 \\
0\end{array}$ & 1 shrub & perennial & wild hydrangea \\
\hline $\begin{array}{l}\text { Hypericum } \\
\text { kalmianum }\end{array}$ & Clusiaceae & native & $\begin{array}{l}1 \\
0\end{array}$ & -1 shrub & perennial & kalms st. johns-wort \\
\hline Iris ?avescens & Iridaceae & non-native & 0 & 2 forb & perennial & pale yellow iris \\
\hline $\begin{array}{l}\text { Lamium } \\
\text { maculatum }\end{array}$ & Lamiaceae & non-native & 0 & 2 forb & perennial & spotted dead nettle \\
\hline $\begin{array}{l}\text { Liquidambar } \\
\text { styraciflua }\end{array}$ & Hamamelidacea & non-native & 0 & -1 tree & perennial & sweet-gum \\
\hline $\begin{array}{l}\text { Liriodendron } \\
\text { tulipifera }\end{array}$ & Magnoliaceae & native & 5 & 1 tree & perennial & tuliptree \\
\hline Magnolia stellata & Magnoliaceae & non-native & 0 & 2 tree & perennial & star magnolia \\
\hline Malus baccata & Rosaceae & non-native & 0 & 2 tree & perennial & siberian crab apple \\
\hline Muscari botryoides & syacinthaceae & non-native & 0 & 2 forb & perennial & grape hyacinth \\
\hline Myosotis sylvatica & Boraginaceae & non-native & 0 & 2 forb & perennial & woodland forget-me-not \\
\hline $\begin{array}{l}\text { Narcissus pseudo- } \\
\text { narcissus }\end{array}$ & Amaryllidaceae & non-native & 0 & 2 forb & perennial & daffodil \\
\hline Nepeta cataria & Lamiaceae & non-native & 0 & 1 forb & perennial & catnip \\
\hline Oenothera biennis & Onagraceae & native & 0 & 1 forb & biennial & kings-cureall \\
\hline $\begin{array}{l}\text { Pachysandra } \\
\text { terminalis }\end{array}$ & Buxaceae & non-native & 0 & 2 shrub & perennial & japanese spurge \\
\hline Panicum capillare & Poaceae & native & 0 & 0 grass & annual & common panic grass \\
\hline Panicum virgatum & Poaceae & native & 3 & 0 grass & perennial & wand panic grass \\
\hline $\begin{array}{l}\text { Pennisetum } \\
\text { alopecuroides }\end{array}$ & Poaceae & non-native & 0 & 2 grass & perennial & foxtail fountain grass \\
\hline
\end{tabular}




\begin{tabular}{|c|c|c|c|c|c|c|}
\hline $\begin{array}{l}\text { Penstemon } \\
\text { calycosus }\end{array}$ & Scrophulariacea & native & 5 & 1 forb & perennial & long-sepal beardtongue \\
\hline $\begin{array}{l}\text { Philadelphus } \\
\text { coronarius }\end{array}$ & Philadelphaceae & non-native & 0 & 2 shrub & perennial & sweet mock orange \\
\hline Phlox maculata & Polemoniaceae & native & 0 & -1 forb & perennial & wild sweetwilliam \\
\hline Phlox paniculata & Polemoniaceae & native & 1 & 1 forb & perennial & fall phlox \\
\hline Phlox pilosa & Polemoniaceae & native & 8 & 1 forb & perennial & downy phlox \\
\hline $\begin{array}{l}\text { Physocarpus } \\
\text { opulifolius }\end{array}$ & Rosaceae & native & 5 & -1 shrub & perennial & atlantic ninebark \\
\hline $\begin{array}{l}\text { Physostegia } \\
\text { virginiana }\end{array}$ & Lamiaceae & native & 4 & -1 forb & perennial & obedient-plant \\
\hline Picea abies & Pinaceae & non-native & 0 & 2 tree & perennial & norway spruce \\
\hline \begin{tabular}{|l} 
Platanus \\
occidentalis
\end{tabular} & Platanaceae & native & 5 & -1 tree & perennial & american sycamore \\
\hline $\begin{array}{l}\text { Polemonium } \\
\text { reptans }\end{array}$ & Polemoniaceae & native & 8 & 0 forb & perennial & greek-valerian \\
\hline \begin{tabular}{|l} 
Populus \\
tremuloides
\end{tabular} & Salicaceae & native & 3 & 0 tree & perennial & quaking aspen \\
\hline Quercus bicolor & Fagaceae & native & 5 & -1 tree & perennial & swamp white oak \\
\hline $\begin{array}{l}\text { Quercus } \\
\text { ellipsoidalis }\end{array}$ & Fagaceae & native & 4 & 2 tree & perennial & hills oak \\
\hline Quercus lyrata & Fagaceae & non-native & 0 & -2 tree & perennial & overcup oak \\
\hline $\begin{array}{l}\text { Quercus } \\
\text { macrocarpa }\end{array}$ & Fagaceae & native & 5 & 0 tree & perennial & burr oak \\
\hline $\begin{array}{l}\text { Quercus } \\
\text { muhlenbergii }\end{array}$ & Fagaceae & native & 8 & 1 tree & perennial & chinkapin oak \\
\hline Quercus rubra & Fagaceae & native & 5 & 1 tree & perennial & northern red oak \\
\hline Quercus velutina & Fagaceae & native & 5 & 2 tree & perennial & black oak \\
\hline $\begin{array}{l}\text { Rhododendron } \\
\text { groenlandicum }\end{array}$ & Ericaceae & native & $\begin{array}{l}1 \\
0\end{array}$ & -2 shrub & perennial & rusty labrador-tea \\
\hline $\begin{array}{l}\text { Rubus idaeus ssp. } \\
\text { idaeus }\end{array}$ & Rosaceae & non-native & 0 & 1 shrub & perennial & common red raspberry \\
\hline Salix fragilis & Salicaceae & non-native & 0 & 2 tree & perennial & crack willow \\
\hline Salix purpurea & Salicaceae & non-native & 0 & \begin{tabular}{|l|l|}
-1 & shrub \\
\end{tabular} & perennial & purple willow \\
\hline Salix $x$ glatfelteri & Salicaceae & native & 2 & -1 tree & perennial & hybrid black willow \\
\hline $\begin{array}{l}\text { Salvia azurea var. } \\
\text { grandi?ora }\end{array}$ & Lamiaceae & non-native & 0 & 2 forb & perennial & blue sage \\
\hline
\end{tabular}




\begin{tabular}{|c|c|c|c|c|c|c|}
\hline $\begin{array}{l}\text { Sambucus nigra } \\
\text { ssp. canadensis }\end{array}$ & Caprifoliaceae & native & 4 & -1 shrub & perennial & black elder \\
\hline $\begin{array}{l}\text { Schizachyrium } \\
\text { scoparium }\end{array}$ & Poaceae & native & 5 & 1 grass & perennial & little false bluestem \\
\hline Scilla non-scripta & Hyacinthaceae & non-native & 0 & 2 forb & perennial & common blue squill \\
\hline Scilla sibirica & Hyacinthaceae & non-native & 0 & 2 forb & perennial & squill \\
\hline Sedum acre & Crassulaceae & non-native & 0 & 2 forb & perennial & mossy stonecrop \\
\hline Silene dioica & Caryophyllaceae & non-native & 0 & 2 forb & perennial & red campion \\
\hline Spiraea japonica & Rosaceae & non-native & 0 & 2 shrub & perennial & japanese meadowsweet \\
\hline $\begin{array}{l}\text { Spiraea } x \\
\text { vanhouttei }\end{array}$ & Rosaceae & non-native & 0 & 2 shrub & perennial & n/a \\
\hline $\begin{array}{l}\text { Sporobolus } \\
\text { heterolepis }\end{array}$ & Poaceae & native & $\begin{array}{l}1 \\
0\end{array}$ & 1 grass & perennial & prairie dropseed \\
\hline Stachys aspera & Lamiaceae & native & $\begin{array}{l}1 \\
0\end{array}$ & -1 forb & perennial & gritty hedge-nettle \\
\hline Stachys byzantina & Lamiaceae & non-native & 0 & 2 forb & perennial & lambs-ears \\
\hline $\begin{array}{l}\text { Symphoricarpos } \\
\text { orbiculatus }\end{array}$ & Caprifoliaceae & non-native & 0 & 1 shrub & perennial & coral-berry \\
\hline $\begin{array}{l}\text { Symphyotrichum } \\
\text { boreale }\end{array}$ & Asteraceae & native & \begin{tabular}{l|}
1 \\
0
\end{tabular} & \begin{tabular}{|l|l|} 
& forb \\
\end{tabular} & perennial & boreal american-aster \\
\hline $\begin{array}{l}\text { Symphyotrichum } \\
\text { oblongifolium }\end{array}$ & Asteraceae & native & 9 & 2 forb & perennial & oblong-leaf aster \\
\hline Taxus cuspidata & Taxaceae & non-native & 0 & 2 shrub & perennial & japanese yew \\
\hline Thuja occidentalis & Cupressaceae & native & $\begin{array}{l}1 \\
0\end{array}$ & \begin{tabular}{|l|l|} 
& \\
tree
\end{tabular} & perennial & eastern arborvitae \\
\hline $\begin{array}{l}\text { Tilia americana } \\
\text { var. neglecta }\end{array}$ & Tiliaceae & native & 1 & 1 tree & perennial & roadside linden \\
\hline Tulipa fosteriana & Liliaceae & non-native & 0 & 2 forb & perennial & emperor tulip \\
\hline $\begin{array}{l}\text { Vaccinium } \\
\text { corymbosum }\end{array}$ & Ericaceae & native & 8 & -1 shrub & perennial & highbush blueberry \\
\hline Vernonia baldwinii & Asteraceae & non-native & 0 & 2 forb & perennial & western ironweed \\
\hline $\begin{array}{l}\text { Veronica } \\
\text { americana }\end{array}$ & $\begin{array}{l}\text { Scrophulariacea } \\
\text { e }\end{array}$ & native & $\begin{array}{l}1 \\
0\end{array}$ & -2 forb & perennial & american brooklime \\
\hline $\begin{array}{l}\text { Viburnum } \\
\text { dentatum }\end{array}$ & Caprifoliaceae & non-native & 0 & 0 shrub & perennial & southern arrow-wood \\
\hline $\begin{array}{l}\text { Viburnum nudum } \\
\text { var. cassinoides }\end{array}$ & Caprifoliaceae & native & \begin{tabular}{l|}
1 \\
0
\end{tabular} & \begin{tabular}{|l|l|}
-1 & shrub \\
\end{tabular} & perennial & possumhaw \\
\hline
\end{tabular}

